\title{
ANNE BABALARIN EBEVEYN DAVRANIŞLARININ VE EVLILLIK DOYUMLARININ İNCELENMESİ
}

Ayşe Gül KAYA ${ }^{1}$

Ahmet BUĞA ${ }^{2}$

\section{$\ddot{O} z$}

$\mathrm{Bu}$ araştırmanın amacı anne babaların ebeveyn davranışları ile evlilik doyumları arasındaki ilişkiyi incelemektir. Çalışmaya çocuğu ilkokul öğrencisi olan 400 ebeveyn katılmıştır. Araştırmada veri toplama aracı olarak Kişisel Bilgi Formu, Ebeveyn Davranışları Ölçeği ve Evlilik Doyum Ölçeği kullanılmıştır. Verilerin analizinde ANOVA, t testi ve Basit Doğrusal Korelasyon analizi kullanılmıştır. Araştırma sonucunda anne babaların ebeveyn davranışlarının cinsiyete, eğitim düzeyine ve evlilik tarzına göre anlamlı olarak farklılaştığı; ebeveyn davranıșlarının yaş, eșler arasındaki yaş farkı ve evlilik süresi değișkenine göre anlamlı olarak farklılaşmadığı bulunmuştur. Yine evlilik doyumu ile cinsiyet, eğitim düzeyi ve evlilik tarzının anlamlı olarak farklılaştığı; yaş, eşler arasındaki yaş farkı ve evlilik süresinin anlamlı olarak farklılaşmadığı bulunmuştur. Ebeveyn davranışları ve evlilik doyumu arasındaki ilişkiye bakılacak olursa, evlilik doyumu arttıkça çocukla ilgilenme ve olumlu ebeveynlik davranışları artmaktadır. Evlilik doyumu azaldıkça zayıf ebeveyn takibi, tutarsız disiplin ve dayakla cezalandırma davranıșlarının arttığı sonucuna ulaşılmıștır. Elde edilen bulgular ebeveyn davranışlarının evlilik doyumu ile ilişkili olduğunu göstermektedir.

Anahtar Kelimeler: Ebeveyn Davranışları, Evlilik Doyumu, Anne ve Baba.

*Bu araştırma Gaziantep Üniversitesi Eğitim Bilimleri Enstitüsünde tamamlanan yüksek lisans tezinden üretilmiştir.

${ }^{1}$ Uzman Psk. Danışman, MEB Özel Gaziantep OSB Mesleki ve Teknik Anadolu Lisesi, Gaziantep, aysegulkaya2793@gmail.com, ORCID: 0000-0001-9971-9864

${ }^{2}$ Dr. Öğr. Üyesi, Gaziantep Üniversitesi Eğitim Fakültesi Eğitim Bilimleri Bölümü Rehberlik ve Psikolojik Danışmanlık Anabilim Dalı, Gaziantep, buga@gantep.edu.tr, ORCID: 0000-0002-95982451

KAYA, A G., BUĞA, A. (2021). Anne Babaların Ebeveyn Davranışlarının ve Evlilik Doyumlarının İncelenmesi. Sosyal Politika Çalışmaları Dergisi, 21(51), 371-410. DOI: 10.21560/spcd.vi.645465 


\title{
EXAMINING OF MOTHERAND FATHER PARENTAL BEHAVIOR AND MARITAL SATISFACTION
}

\begin{abstract}
The purpose of this research is to investigate the relationship between parental behaviors of parents and marriage satisfaction. 400 parents whose children were studying in primary school participated in the study. Personal information form, parental behaviors scale and marital satisfaction scale have been used in the research. ANOVA, $t$ test and Simple Linear Correlation were used for data analysis. When it is looked in to the results; parental behavior depicts reasonable differences according to the gender, education level and marriage kinds but not depicts reasonable differences according to the age, age difference between spouses and duration of marriage. Marital satisfaction depicts reasonable differences according to the gender, education level and marriage kinds but not depicts reasonable differences according to the age, age difference between spouses and duration of marriage. As a result of the analysis to determine the relationship between parental behaviors and marital satisfaction, as marriage satisfaction increases, involvement and positive parenting increase. We conclude that as marriage satisfaction decreases, poor monitoring/supervision, inconsistent discipline and corporal punishment increase. Findings show that Parenting behaviors are related to marital satisfaction.
\end{abstract}

Keywords: Parenting behavior, marital satisfaction, mother and father. 


\section{GİRIŞ}

Evlilik, kadın ve erkeğin aile yaşamına girmesine izin veren veya aile yaşamını kabul eden önemli bir sosyal sistemdir (Chandrakanth, 2015). Evlilik toplum tarafından belirlenen kurallar çerçevesinde birlikteliği sağlayan bir yoldur (Özabac1, Körük ve Kara, 2019). Bununla beraber evlilik, kişilik gelişimi ve öznel mutluluğa katkı sağlayan bir kurumdur (Glenn, 1991). Diğer önemli görevler ise, ortak sorumluluk almak, çatışmaları etkin şekilde çözmek ve ailenin yeni üyeleriyle yaşamaya alışmaktır (Canel, 2007).

Bireylerin evliliklerinden duydukları duygular, beklentiler, davranışsal kazanımlar çeşitli kavramlarla ifade edilmektedir. Evlilik doyumu da bu kavramlardandır. Evlilik doyumu ile ilgili literatürde çok fazla tanım vardır. Evlilik doyumu kişinin evliliğindeki ihtiyaçlarının giderilmesi olarak tanımlanmıştır (Tezer, 1996). Evlilik doyumu evlilik süresince eşlerin birbirlerinden ve evlilikten sağladığı tatmindir ve evlilik doyumunun evliliğin uzun vadeli olması ile ilişkisi bulunmaktadır (Hamurcu, 2018). Evlilik doyumu genellikle kişinin kendi evliliğinin kalitesi ile ilgili memnuniyet durumuna atıfta bulunur (Guerro ve Eloy, 1992).Evlilik doyumu, aile birlikteliği ve kişisel gelişimin önemli bir bileşenidir (Angusamy, Kuppusamy, Anantharaman ve Syafiqah, 2017).Evlilik doyumu evliliğin sürekli olması, huzurlu aile ortamı ve aile sıcaklığı, bireylerin psikolojik sağlıklarını etkilemesi yönünden aktif rol oynamaktadır. Kişilerin evliliklerindeki doyum, yaşamlarının birçok yönüne etki eder ve katkı sağlar. Tezer (1994) eşlerin evliliklerinden duydukları mutluluğun ve genel iyi oluş halinin, iş doyumundan daha önemli olduğu sonucuna ulaşmıştır. Soylu ve Kabasakal (2016) evli kadınların evlilik doyumu ve yaşam doyumu arasında pozitif ve orta düzeyde anlamlı bir ilişki olduğu sonucuna varmıştır. Jouriles, Bourg ve Farris (1991) 6-12 yaş arası 1747 çocuk ile yaptığı araştırmasında evlilik doyumu ile çocuk davranış problemleri arasında anlamlı ilişki olduğu sonucuna ulaşmıştır. Fıne, Voydanoff Ve Donnelly (1994) çocuğun genel mutluluk algılarının aile yapısı, ebeveyn depresyonu ve evlilik doyumu ile ne ölçüde ilişkili olduğunu araştırdığı çalışmasında çocuğun mutluluğu ile ebeveynlerinin evlilik doyumu arasında olumlu yönde ilişki olduğunu bulmuştur. 
Evlilik toplumsal ilkeleri içine alan aileyi oluşturur. Aile kurumunun birçok işlevi bulunmaktadır. Bunlar, sevme, sevilme, cinsel doyuma ulaşma, neslin devamını sağlama, çocuğun bakımını sağlama, toplumsal statü elde etmedir (Özer, 2016).

Evlilik ve ailenin birbiriyle iç içe geçmiş olması, evlilik ve aile doyumlarını karşılıklı olarak etkilemektedir. Evlilikte yaşanan sorunlara mantıklı çözümler üretilememesi evlilik doyumu azalttığ 1 gibi, eşlerin ve çocukların da ruh sağlıklarının olumsuz etkilenmesine yol açmaktadır. Twenge, Campbell ve Foster (2003) yaptıkları çalışmada ebeveyn olmanın evlilik doyumunda en büyük etkiye sahip olduğu sonucuna ulaşmışlardır. Evlilik doyumu sağlıklı ailelerin ana faktörlerindendir (Greff, 2000). Ailenin tartışmasız en önemli görevlerinden biri çocuk yetiştirmek ve çocuğa bakmaktır. Güçlü aile, kaynağını güçlü evliliklerden alır, güçlü evlilikler ise sağlıklı çift ilişkisinden beslenir. Sağlıklı çiftlerin sahip olduğu çocuk da sağlıklı olmakta ve çocuk yetişkinlik hayatına kadar anne baba ilişkisinden beslenmektedir (Canel, 2007).

Çocuk ailesinin bir uzantısıdır ve ailesinde ne öğreniyorsa onu hayata geçirir. Ailesinden, anne babasından sevgi, ilgi, değer görmemiş bir çocuk hayata karşı dezavantajlı bir durumdadır. Anne babanın çocuğa olan tutumu ve davranışları çok önemlidir çünkü bu tutum ve inançlar ileride çocuğun hayatına yansıyacaktır nitekim anne babaların çocuklarına olan tutum ve davranışları; ebeveynin kendi çocukluğundaki gelişimi, aile yapısı, ailesinde gelişirken kendi uyumsuzluklarının nasıl yorumlandığının sonucunu gösterir (Kaya, 2005). Bundan ötürüdür ki çocuğun anne babasından gördüğü tutum davranış önemli, bu tutum ve davranışların çocuğa nasıl yansıdığı daha da önemlidir.

Bu bağlamda ebeveyn davranışları ile çocuk davranışı arasında güçlü bir ilişki vardır, bu da olumlu ebeveyn davranışlarının düşük çocuk davranış sorunu oranları ile ilişkili olduğunu göstermektedir (Sebre, Jusiene, Dapkevice, Skreitule-Pikse ve Bieliauskaite, 2014).Anne babanın çocuğa karş1 sergiledikleri tutum ve davranışları, çocuğun ileriki yaşamında göstereceği davranışları, başvuracağı problem ve çatışma çözme davranışlarını etkilemekte ve geliştirmektedir. Anne-baba arasında uyumlu ilişkinin olmayışı çocuğun 
ileriki yaşamında uyum güçlüğü çekmesine neden olur. Anne-baba ve çocuğun ilişkisinin kalitesi, çocuğun topluma uyum becerilerinin yordayıcısıdır (Öngel Atar, Yalçın, Uygun, Çiftçi Demirci ve Erdoğan, 2016). Ebeveynler küçük çocukların ilk rol modeli oldukları için, ebeveynlerinin yardımı ile temel becerileri öğrenebilir ve sağllklı yetişkin olabilirler (Çelebi Öncü ve Ünlüer, 2012). Eşler arasında kurulan dengeli ve sağlıklı ilişkiler çocuğun kişilik özellikleri ve davranışlarını olumlu yönde etkiler (Semiz, 1998 akt. Eminoğlu, 2007).Ebeveyn davranışları, çocuk ve ergen gelişimindeki tüm dönemlerde suçluluk, sosyal beceriler ve okul performansı gibi gençlik davranışlarıyla sıklıkla bağlantılıdır (Gross, Fleming, Mason, ve Haggerty, 2015).Öngel Atar, Yalçın, Uygun, Çiftçi Demirci ve Erdoğan (2016) tarafından yapılan çalışmada madde kullanım bozukluğu olan ergenlerde kontrol grubu ile kıyaslandığında anne baba birlikteliğinin düşük olduğu, ebeveynlerinde çift uyumun düşük olduğu, aile özelliklerinde ve aile içi etkileşimde "problem çözme", "iletişim", "roller", "duygusal tepki verebilme", "gereken ilgiyi gösterme", "davranı̧̧ kontrolü”, "genel işlevler" boyutlarında problem yaşandığı saptanmıştır.

Kaya (2003), 8-10 yaşları arasında çocuğu olan 84 anne baba ile çalışmıştır. Evlilik uyumu, çocuklardaki davranış problemleri ve anne babaların çocuk yetiştirme tutumlarını araştırmıştır. Bulgulara göre, çocuk davranış problemleri, annelerin saldırganlık ve kin davranışı ile evlilik uyumu anlamlı olarak değişmektedir. Annelerin evlilik uyumu arttıkça çocuk davranış problemleri azalmaktadır. Anneler evlilik uyumunda sorun yaşadıkça çocuklarına daha duyarsız olmaktadır. Fishman ve Meyers (2000), evlilikte doyumsuzluk yaşayan annelerin çocuklarıyla daha az ilgilendiğini ve bunun daha büyük çocuk psikolojik sıkıntılarıyla ilişkili olduğu tespit etmiştir. Okul öncesi çağında çocuğu olan 96 evli çiftten oluşan araştırmada, genel olarak, daha tatmin edici ve destekleyici evliliklerdeki ebeveynler, çocuklarını daha olumlu görmüş ve çocukları için daha yüksek standartlar koymuştur (Goldberg, 1990).

Alan yazın incelendiğinde, evlilik doyumunun: iş doyumu (Tezer, 1994), evlilik çatışması (Howes ve Markman, 1989), dine bağlılık (Uçar, 2018), stresle baş etme (Yüksel ve Dağ, 2015), toplumsal cinsiyet rolü (Yılmaz, 2015), bağlanma stili (Yıldız, 2018), umutsuzluk düzeyleri, depresyon-kaygı, 
erken dönem şemalar, anne baba tutumları (Yıldız, 2013), duyguları ifade etme biçimi (Yıldırım, 2017), bağlanma boyutları (Yanar Güngör, 2019), çalışma statüsü ve iletişim tarzları (Uçak, 2018), benlik saygısı, yaş, cinsiyet, sosyoekonomik düzey, eğitim düzeyi, evlenme tarzı (Yıldırım, 2017), evlilik süresi gibi değiş̧kenlerle ilişkili olarak ele alındığı görülmektedir. Bu bağlamda alanda evlilik doyumu ile çeşitli değişkenler arasındaki çalışmalar görülmekle birlikte evlilik doyumu ve ebeveyn davranışlarının arasındaki ilişkiyi inceleyen çalışmaların olmaması dikkat çekmiştir. Evlilik doyumu ile anne baba tutumları arasındaki ilişki daha çok araştırma konusu olmuştur (Garip, 2010; Sevinç ve Garip, 2010; Yalçın ve Türnüklü, 2011; Yıldız, 2013; Yücel, 2013; Karasan, 2015; Çakır, 2017; Doğru, 2017; Güren, 2017). Ebeveynlerin çocuklarına yönelik sergiledikleri davranışların incelenmesi bu araştırmayı diğer anne baba tutum ve tarzı ile çalışan araştırmalardan ayırmaktadır.

Evlilik doyumu anne babanın mutluluğunu, ruh sağlıklarını etkilemektedir. Anne babaların evlilik doyumundan sağladıkları doyum da çocuklarına olan davranışlarını, ebeveynliklerini etkilemekte ve bu durum çocuğa yansımaktadır. Çocuk davranışları, anne babanın davranışlarından etkilenmektedir. $\mathrm{Bu}$ bilgiler 1şı̆̆ında bireylerin ebeveyn davranışları ile evlilik doyumu arasında bir ilişki olabileceği sonucuna varılmıştır. Bu nedenle de ebeveyn davranışları ile evlilik doyumu arasındaki ilişki incelenmeye değer görülmüştür ve bu çalışmanın alan yazına katkı sağlayacağ 1 düşünülmüştür. Bu bağlamda bu araştırmada çocuğun gelişiminde ve çocuğun erken dönemde edindiği duygu, düşünce ve davranışlarda etkili olan ebeveyn davranışları ile evlilik doyumu arasındaki ilişkinin incelenmesi amaçlanmıştır.

\section{YÖNTEM}

$\mathrm{Bu}$ araştırma, ilişkisel tarama modeli ile gerçekleştirilmiştir. İlişkisel tarama modeli iki veya daha çok sayıdaki değişkenin ve bu değişkenlerin aralarındaki ilişkilerin belirlenmesi için yapılan araştırma modelleridir (Büyüköztürk, 2015).

\section{1.Çalışma Grubu}

Araştırmanın çalışma grubunu Gaziantep ilinde yaşayan, 20-50 yaşlar arasında evli ve çocuğu ilkokula giden 277 kadın ve 123 erkek ebeveyn, toplam 400 kişi oluşturmaktadır. Araştırmaya katılım gönüllülük esasına göre 
sağlanmıştır. Çalışma grubunu belirlemede basit seçkisiz örnekleme yöntemi kullanılmıştır. Araştırma grubunda yer alan bireylere ilişkin tanımlayıcı bilgiler Tablo 1'de sunulmuştur.

Tablo.1. Araştırmaya katılan ebeveynlere ait sosyodemografik bilgiler

\begin{tabular}{|c|c|c|c|c|c|}
\hline Cinsiyet & Frekans (n) & Yüzde(\%) & Cinsiyet & Frekans (n) & Yüzde(\%) \\
\hline Anne & 277 & 69,3 & \multicolumn{3}{|c|}{ Ebeveyn Eğitim Durumu } \\
\hline Baba & 123 & 30,8 & \multirow{2}{*}{$\begin{array}{l}\text { Okuma yazma } \\
\text { bilmeyen }\end{array}$} & \multirow[t]{2}{*}{5} & \multirow[t]{2}{*}{1,3} \\
\hline Toplam & 400 & 100 & & & \\
\hline \multicolumn{3}{|l|}{ Ebeveyn Yaşı } & \multirow{2}{*}{$\begin{array}{l}\text { Okuma yazma } \\
\text { bilen fakat bir okul } \\
\text { bitirmeyen }\end{array}$} & \multirow[t]{2}{*}{15} & \multirow[t]{2}{*}{3,8} \\
\hline $20-30$ & 67 & 16,8 & & & \\
\hline $31-40$ & 295 & 73,8 & illkokul mezunu & 118 & 29,5 \\
\hline $41-50$ & 26 & 6,5 & Ortaokul mezunu & 79 & 19,8 \\
\hline Toplam & 388 & 97 & Lise mezunu & 98 & 24,5 \\
\hline \multicolumn{3}{|l|}{ Eş ile yaş farkı } & Yüksekokul mezunu & 10 & 2,5 \\
\hline $0-5$ yaş & 280 & 70 & Üniversite mezunu & 65 & 16,3 \\
\hline 6-10 yaş & 116 & 29 & \multirow{2}{*}{$\begin{array}{l}\text { Yüksek lisans ve } \\
\text { üzeri mezunu }\end{array}$} & \multirow[t]{2}{*}{10} & \multirow[t]{2}{*}{2,5} \\
\hline Toplam & 396 & 99 & & & \\
\hline Evlenme Tarzı & & & Toplam & 400 & 100 \\
\hline Görücü usulü & 252 & 63 & \multicolumn{3}{|l|}{ Evlilik Süresi } \\
\hline Tanışıp anlaşarak & 147 & 36,8 & $0-10$ yıl & 117 & 29,3 \\
\hline Toplam & 399 & 99,8 & $11-20 \mathrm{yll}$ & 242 & 60,5 \\
\hline \multicolumn{3}{|c|}{ Sosyoekonomik Durum } & 20 ve üzeri yıl & 29 & 7,2 \\
\hline Düşük & 220 & 55 & Toplam & 388 & 97 \\
\hline Orta & 137 & 34,3 & & & \\
\hline Yüksek & 31 & 7,8 & & & \\
\hline Toplam & 251 & 97 & & & \\
\hline
\end{tabular}




\section{Veri Toplama Araçları}

Araştırmada veri toplama amacıyla; Ebeveyn Davranışları Ölçeği, Evlilik Doyumu Ölçeği ve Kişisel Bilgi Formu kullanılmıştır.

Ebeveyn Davranışları Ölçeği: Frick (1991) tarafından geliştirilen ve Çekiç, Türk, Buğa ve Hamamcı (2018) tarafından Türkçe 'ye uyarlanan ölçek ebeveynlerin çocuklarına karşı sergiledikleri davranışlar ve uygulamaları ölçmektedir. Ebeveyn Davranışları Ölçeği toplam 42 maddeden oluşmaktadır. Ölçeğin 35 maddesi ebeveyn davranışlarını 5 farklı boyutta incelemektedir. Bunlar; Çocukla İlgilenme (Çİ), Olumlu Ebeveynlik (OE), Zayıf Ebeveyn Takibi (ZET), Tutarsız Disiplin (TD) ve Dayakla Cezalandırma (DC) dır. Ayrıca ölçekte Dayakla Cezalandırma alt boyutunun dışında başka disipline etme şekillerine dair 7 madde daha vardır (34, 36, 37, 39, 40, 41, 42. Maddeler). Bu maddeler bir alt boyut olarak puanlanmamakta, sadece DC alt boyutuna karş1 anne babalar tarafından bir önyargı gelişmesin diye ölçek uygulamalarında kullanılmaktadır (Shelton, Frick \& Woolton, 1996). Ölçekte yer alan Çİ ve OE alt boyutları ebeveynlikle ilgili olumlu davranışları ölçerken, ZET, TD ve DC alt boyutları ise olumsuz ebeveyn davranışlarını ölçmektedir (Frick, 1991). Ölçek puanlanmasında toplam puan alınmamaktadır. AEDÖ maddelerinden elde edilen iç tutarlılık katsayıları .46 ile .77 arasında değişmektedir. Çocukla İlgilenme: .77, Olumlu Ebeveynlik: .68, zayıf Ebeveyn Takibi: .65, Tutarsız Ceza: .46 ve Dayakla Cezalandırma: .70'dir. Yapılan geçerlilik analizi sonucunda KMO değeri .77 bulunmuştur ve faktörleşmeye uygun olduğu görülmüştür (Çekiç vd., 2018).

Evlilik Doyum Ölçeği: Ölçek Canel (2007) tarafından geliştirilmiştir ve doğru ve yanlış olmak üzere iki seçenekli olarak işaretlenmektedir(Canel, 2007). Ölçek çocuk sahibi olan bireyler için toplam 101 maddeden, çocuğu olmayan bireyler için 92 maddeden oluşmaktadır. Ölçeğin amacı bireyin evlilik doyumuna ait olumsuz bakış açısını ortaya koymaktır bu sebeple ölçekten alınan yüksek puan düşük evlilik doyumuna, ölçekten alınan düşük puan yüksek evlilik doyumuna işarettir. Ölçekte olumsuz ifadeli cevaplar 1 puan alır, olumlu ifadeler 0 puan olarak değerlendirilmektedir. EDÖ'nin iç tutarlılığı, ölçeğin tümü ve her bir alt ölçek için ayrı ayrı hesaplanmıştır. İç tutarlılık güvenirlik katsayısı ölçeğin tümü için. 97, alt ölçekler için ise 
sirasiyla. $97, .85, .84, .73$ ve. 86 olarak hesaplanmıştır (Canel, 2007). Ölçeğin 5 alt boyutu bulunmaktadır. Evlilik Uyumu, Öfke, Eşin Ailesiyle İletişim, Ekonomik anlayış ve Ebeveynlik Anlayışıdır.

Kişisel Bilgi Formu: Araştırmacı tarafından hazırlanan Kişisel Bilgi Formu toplam 11 sorudan oluşmaktadır. Bunlar; ebeveyni olunan çocuğun kaçıncı sınıfta okuduğu, katılımcının yaşı, cinsiyeti, eşi ile arasındaki yaş farkı, sosyoekonomik durum, kişinin büyüdügü yer, meslek, eşin mesleği, eğitim düzeyi, evlilik kararını alma şekli ve evlilik süresi vb. ilişkin sorular yer almaktadır.

\section{Verilerin Analizi}

Verilerin analizi için SPSS.21 paket programı kullanılmıştır. Verilerin normal dağılım göstermesi parametrik olan testlerin temel varsayımlarından biridir. $\mathrm{Bu}$ varsayımın karşılanıp karşılanmadı̆̆ını test etmek amacıyla katılımcıların AEDÖ ve EDÖ'den elde ettikleri puanların çarpıklık (skewness) ve basıklık (kurtosis) katsayıları incelenmiştir. Katılımcıların AEDÖ'nin alt boyutlarından elde ettikleri puanlara ilişkin çarpıklık ve basıklık katsayılarına bakıldığında tüm alt boyutlarına ait katsayıların -1,96 ile $+1,96$ Aralığında olduğu yani normal bir dağılım sergilediği görülmektedir. Sürekli bir değişkene ait verilerin normal dağılım gösterip göstermediğine bakılırken birkaç yöntem izlenmektedir. Bunlardan biri de çarpıklık ve basıklık kat sayılarının -1,96 ile $+1,96$ arasında yer aldığ 1 takdirde verilerin normal dağılım gösterdiği söylenebilmektedir (Can, 2014). EDÖ'den elde edilen puanlara ilişkin basıklık çarpıklık katsayılarına bakıldığında ise yine basıklık ve çarpıklık katsayısının -1,96 ile $+1,96$ Aralığında olduğu ve normal dağılım gösterdiği görülmektedir. $\mathrm{Bu}$ sebeple katılımcıların puanlarının çeşitli değişkenlere göre farklılaşıp farklılaşmadığını incelemek amacıyla İlişkisiz örneklemler için t-testinin ile İlişkisiz örneklemler için tek faktörlü ANOVA; ebeveyn davranışlarının kişilerin evlilik doyumu ile olan ilişkisini incelemek amacıyla ise Pearson Moment Çarpım Korelasyon analizlerinden yararlanılmıştır. 


\section{BULGULAR}

\section{Alabama Ebeveyn Davranışları Ölçeği ile Evlilik Doyumu Ölçeği} Puan Ortalamalarından Elde Edilen Bulgular

Tablo 2. Araştırmaya katılan ebeveynlerin Alabama Ebeveyn Davranışları Ölçeği ve Evlilik Doyumu Ölçeğinden Elde Ettikleri Puanlara Ait Aritmetik Ortalama ve Standart Sapma Değerleri

\begin{tabular}{|l|l|l|l|}
\hline Boyutlar & $\boldsymbol{N}$ & $\mathrm{X}$ & $\mathbf{S s}$ \\
\hline AEDÖ-Çİ & 400 & 39,47 & 5,59 \\
\hline AEDÖ-OE & 400 & 25,67 & 3,4 \\
\hline AEDÖ-ZET & 400 & 16,25 & 6,09 \\
\hline AEDÖ-TD & 400 & 15,58 & 3,57 \\
\hline AEDÖ-DC & 400 & 5,28 & 2,06 \\
\hline EDÖ & 400 & 40,02 & 20,48 \\
\hline
\end{tabular}

AEDÖ: Alabama Ebeveyn Davranıșları Ölçeği, AEDÖ-Çİ: Çocukla İlgilenme Alt Boyutu, AEDÖOE: Olumlu Ebeveynlik Alt Boyutu, AEDÖ-ZET: Zayıf Ebeveyn Takibi Alt Boyutu, AEDÖ-TD: Tutarsız Disiplin Alt Boyutu, AEDÖ-DC: Dayakla Cezalandırma Alt Boyutu, EDÖ: Evlilik Doyumu Ölçeği.

Tablo 2'ye göre araştırmaya katılan ebeveynlerin AEDÖ’nin Çocukla İlgilenme alt boyutundan elde ettikleri puanların ortalaması 39,47 (Ss: 5,59), AEDÖ'nin Olumlu Ebeveynlik alt boyutundan elde ettikleri puanların ortalaması 25,67 (Ss: 3,4), AEDÖ'nin Zayıf Ebeveyn Takibi alt boyutundan elde ettikleri puanların ortalaması 16,25 (Ss: 6,09), AEDÖ’nin Tutarsız Disiplin alt boyutundan elde ettikleri puanların ortalaması 15,58 (Ss: 3,57), AEDÖ’nin Dayakla Cezalandırma alt boyutundan elde ettikleri puanların ortalaması 5,28 (Ss: 2,06) ve EDÖ'den aldıkları puanların ortalaması 40,02 (Ss: 20,48) olarak belirlenmiştir. 


\section{Cinsiyete Göre Elde Edilen Bulgular}

Tablo 3. Alabama Ebeveyn Davranışları Ölçeği ve Evlilik Doyum Ölçeği Puanlarının Ebeveynin Cinsiyetine Göre Farklılaşıp Farklılaşmadığını Belirlemek Üzere Yapılan İlişkisiz Örneklem T Testi Sonuçları

\begin{tabular}{|c|c|c|c|c|c|c|c|c|}
\hline & $\begin{array}{l}\text { Ölçekler ve Alt } \\
\text { boyutlar }\end{array}$ & Gruplar & $N$ & $\bar{X}$ & SS & $t$ & $d f$ & $p$ \\
\hline \multirow{10}{*}{$\begin{array}{l}\text { 常 } \\
\text { o: }\end{array}$} & \multirow{2}{*}{ AEDÖ-çi } & Anne & 277 & 40,5 & 5,28 & 2,797 & 398 & $0,005^{*}$ \\
\hline & & Baba & 123 & 38,9 & 6,01 & & & \\
\hline & \multirow{2}{*}{ AEDÖ-OE } & Anne & 277 & 25,9 & 3,24 & 1,635 & 398 & 0,103 \\
\hline & & Baba & 123 & 25,3 & 3,7 & & & \\
\hline & \multirow{2}{*}{ AEDÖ-ZET } & Anne & 277 & 15,8 & 5,95 & $-2,045$ & 398 & $0,041^{*}$ \\
\hline & & Baba & 123 & 17,2 & 6,34 & & & \\
\hline & \multirow{2}{*}{ AEDÖ-TD } & Anne & 277 & 15,6 & 3,59 & $-0,303$ & 398 & 0,762 \\
\hline & & Baba & 123 & 15,7 & 3,53 & & & \\
\hline & \multirow{2}{*}{ AEDÖ-DC } & Anne & 277 & 5,3 & 1,95 & 0,357 & 398 & 0,721 \\
\hline & & Baba & 123 & 5,22 & 2,3 & & & \\
\hline \multirow{7}{*}{ 男: } & \multirow{2}{*}{ EDÖ-EU } & Anne & 277 & 15,8 & 14,3 & 0,24 & 398 & 0,811 \\
\hline & & Baba & 123 & 15,4 & 14,5 & & & \\
\hline & \multirow{2}{*}{ EDÖ-EA } & Anne & 277 & 2,99 & 2,58 & 4,495 & 286 & $0,000 * *$ \\
\hline & & Baba & 123 & 1,8 & 2,08 & & & \\
\hline & \multirow{2}{*}{ EDÖ-TOPLAM } & Anne & 277 & 25,9 & 20,4 & 1,258 & 398 & 0,209 \\
\hline & & Baba & 123 & 23,1 & 20,6 & & & \\
\hline & \multicolumn{8}{|c|}{$* p<.05, * * p<.001$} \\
\hline
\end{tabular}

AEDÖ: Alabama Ebeveyn Davranıșları Ölçeği, AEDÖ-Çİ: Çocukla İlgilenme Alt Boyutu, AEDÖOE: Olumlu Ebeveynlik Alt Boyutu, AEDÖ-ZET: Zayıf Ebeveyn Takibi Alt Boyutu, AEDÖ-TD: Tutarsız Disiplin Alt Boyutu, AEDÖ-DC: Dayakla Cezalandırma Alt Boyutu, EDÖ: Evlilik Doyumu Ölçeği.

Tablo 3 incelendiğinde 277 anne ve 123 babadan oluşan 400 kişilik bir grupta annelerle babaların Alabama Ebeveyn Davranışları Ölçeğinin alt boyutlarından elde ettikleri puanlar arasında anlamlı bir fark olup olmadığını ortaya koymak adına yapılan İlişkisiz Örneklem T Testi sonuçlarına göre; Çocukla İlgilenme $[\mathrm{t}(398)=2,797, \mathrm{p}<.05]$ ve Zayıf Ebeveyn Takibi $[\mathrm{t}(398)=$ 
$-2,045, \mathrm{p}<.05]$ alt boyutları arasında annelerin puanları ile babaların puanları arasında istatistiksel olarak anlamlı bir fark olduğu gözlenmiştir. Çocukla İlgilenme puanı açısından annelerin puan ortalaması $(40,53)$ babaların puan ortalamasından $(38,86)$ daha yüksek olup istatistiksel olarak anlamlı fark vardır. Zayıf Ebeveyn Takibi puanı açısından babaların puan ortalaması $(17,18)$ annelerin puan ortalamasindan $(15,83)$ daha yüksek olup istatistiksel olarak anlamlı farklılık bulunmaktadır. Diğer yandan Olumlu Ebeveynlik [t(398) $=1,635, \mathrm{p}>.05]$, Tutarsiz Disiplin [t(398) $=-0,303, \mathrm{p}>.05$ ] ve Dayakla Cezalandırma $[\mathrm{t}(398)=0,357, \mathrm{p}>.05]$ alt boyutları arasında anlamlı bir fark olmadığı belirlenmiştir.

EDÖ-Ebeveynlik Anlayışı [ $\mathrm{t}(286)=4,495, \mathrm{p}<$.05] alt boyutu arasında annelerin puanları ile babaların puanları arasında istatistiksel olarak anlamlı bir fark olduğu gözlenmiştir. Babaların ebeveynlik anlayışı, annelerin ebeveynlik anlayışından yüksek derece anlamlı olarak farklılaşmaktadır. Diğer yandan EDÖ-Toplam [t(398)= 1,258, p > .05] ve EDÖ-Evlilik Uyumu [t(398)= $0,24, \mathrm{p}>.05$ ] alt boyutları arasında anlamlı bir fark olmadığ belirlenmiştir. 


\section{Yaşa Göre Elde Edilen Bulgular}

Tablo 4. Alabama Ebeveyn Davranışları ve Evlilik Doyumu Ölçeği Puanlarının Ebeveynin Yaşı Değişkenine Göre Farklılaşıp Farklılaşmadığını Belirlemek Üzere Yapılan İlişkisiz Örneklemler İçin Tek Yönlü Varyans Analizi (ANOVA) Sonuçları

\begin{tabular}{|c|c|c|c|c|c|c|c|c|c|}
\hline \multirow{2}{*}{\multicolumn{2}{|c|}{$\begin{array}{l}\text { Ölçekler ve Alt } \\
\text { boyutlar }\end{array}$}} & \multicolumn{2}{|c|}{$\begin{array}{c}\text { A } \\
20-30 \text { Yaş } \\
\mathrm{N}: 67\end{array}$} & \multicolumn{2}{|c|}{$\begin{array}{c}\text { B } \\
31-40 \text { Yaş } \\
\mathrm{N}: 295\end{array}$} & \multicolumn{2}{|c|}{$\begin{array}{c}\text { C } \\
41-50 \text { Yaş } \\
\text { N: } 26\end{array}$} & \multirow[t]{2}{*}{$F$} & \multirow[t]{2}{*}{$p$} \\
\hline & & $\bar{X}$ & ss & $\bar{x}$ & ss & $\bar{x}$ & ss & & \\
\hline \multirow{5}{*}{ 惫 } & AEDÖ-Çi & 40,4 & 5,61 & 40,1 & 5,42 & 38 & 6,72 & 1,81 & 0,17 \\
\hline & AEDÖ-OE & 26 & 3,61 & 25,7 & 3,29 & 24,5 & 4,3 & 1,78 & 0,17 \\
\hline & AEDÖ-ZET & 16,1 & 5,63 & 16,1 & 6,09 & 17,8 & 7,09 & 0,95 & 0,39 \\
\hline & AEDÖ-TD & 15,1 & 3,54 & 15,7 & 3,54 & 15,9 & 3,57 & 0,84 & 0,43 \\
\hline & AEDÖ-DC & 5,36 & 1,74 & 5,2 & 2,02 & 5,54 & 2,81 & 0,45 & 0,64 \\
\hline \multirow{3}{*}{ O̊ } & EDÖ-EU & 14,6 & 12,8 & 15,3 & 14,4 & 19,5 & 15,5 & 1,17 & 0,31 \\
\hline & EDÖ-EA & 2,91 & 2,22 & 2,52 & 2,53 & 2,65 & 2,65 & 0,66 & 0,52 \\
\hline & EDÖ-TOPLAM & 24,4 & 17,7 & 24,3 & 20,7 & 29,7 & 23,3 & 0,84 & 0,43 \\
\hline
\end{tabular}

AEDÖ: Alabama Ebeveyn Davranışları Ölçeği, AEDÖ-Çİ: Çocukla İlgilenme Alt Boyutu, AEDÖOE: Olumlu Ebeveynlik Alt Boyutu, AEDÖ-ZET: Zayıf Ebeveyn Takibi Alt Boyutu, AEDÖ-TD: Tutarsız Disiplin Alt Boyutu, AEDÖ-DC: Dayakla Cezalandırma Alt Boyutu, EDÖ: Evlilik Doyumu Ölçeği.

Tablo 4 incelendiğinde ebeveynlerin AEDÖ’ nin alt boyutlarından aldıkları puanlar arasında ebeveynin yaşı değişkenine göre bir fark olup olmadığına ilişkin yapılan İlişkisiz Örneklemler İçin Tek Yönlü Varyans Analizi (ANOVA) sonuçlarına göre, ebeveynlerin Çocukla İlgilenme $[\mathrm{F}(2-385)=1,806, \mathrm{p}>.05]$, Olumlu Ebeveynlik $[\mathrm{F}(2-385)=1,783, \mathrm{p}>.05]$, Zayıf Ebeveyn Takibi $[\mathrm{F}(2-$ $385)=0,954, \mathrm{p}>.05]$, Tutarsiz Disiplin $[\mathrm{F}(2-385)=0,835, \mathrm{p}>.05]$ ve Dayakla Cezalandırma $[\mathrm{F}(2-385)=0,447, \mathrm{p}>.05]$ alt boyutlarından elde ettikleri puanların ortalamaları arasında anlamlı bir fark gözlenmemiştir. 
Yine ebeveynlerin EDÖ-Evlilik Uyumu $[\mathrm{F}(2-385)=1,166, \mathrm{p}>$.05], EDÖEbeveynlik Anlayışı $[\mathrm{F}(2-385)=0,658, \mathrm{p}>.05]$ alt boyutları ve EDÖ-toplam $[\mathrm{F}(2-385)=0,839, \mathrm{p}>.05]$ elde ettikleri puanların ortalamaları arasında anlamlı bir fark gözlenmemiştir.

\section{Eșler Arasındaki Yaș Farkına Göre Elde Edilen Bullgular}

Tablo 5. Alabama ebeveyn davranıșları ve evlilik doyumu ölçeği puanlarının ebeveynin eși ile arasındaki yaş farkına göre farklılaşıp farklılaşmadığını belirlemek üzere yapılan ilişkisiz örneklem t testi sonuçları

\begin{tabular}{|c|c|c|c|c|c|c|c|c|}
\hline & $\begin{array}{l}\text { Ölçekler ve } \\
\text { Alt boyutlar }\end{array}$ & Gruplar & $N$ & $\bar{X}$ & SS & $t$ & $d f$ & $p$ \\
\hline \multirow{10}{*}{$\begin{array}{l}\text { 省 } \\
\text { O: }\end{array}$} & \multirow{2}{*}{ AEDÖ-Çi } & $0-5$ yıl & 280 & 39,86 & 5,47 & \multirow{2}{*}{$-0,96$} & \multirow{2}{*}{394} & \multirow{2}{*}{0,338} \\
\hline & & 6-10 yıl & 116 & 40,45 & 5,78 & & & \\
\hline & \multirow{2}{*}{ AEDÖ-OE } & $0-5 \mathrm{yıl}$ & 280 & 25,58 & 3,29 & \multirow{2}{*}{$-0,711$} & \multirow{2}{*}{394} & \multirow{2}{*}{0,478} \\
\hline & & 6-10 yıl & 116 & 25,84 & 3,66 & & & \\
\hline & \multirow{2}{*}{ AEDÖ-ZET } & $0-5$ yıl & 280 & 16,28 & 6,21 & \multirow{2}{*}{0,159} & \multirow{2}{*}{394} & \multirow{2}{*}{0,873} \\
\hline & & 6-10 yıl & 116 & 16,17 & 5,81 & & & \\
\hline & \multirow{2}{*}{ AEDÖ-TD } & $0-5 \mathrm{yıl}$ & 280 & 15,59 & 3,47 & \multirow{2}{*}{0,215} & \multirow{2}{*}{394} & \multirow{2}{*}{0,83} \\
\hline & & 6-10 yıl & 116 & 15,51 & 3,82 & & & \\
\hline & \multirow{2}{*}{ AEDÖ-DC } & $0-5$ yıl & 280 & 5,2 & 2,1 & \multirow{2}{*}{$-1,031$} & \multirow{2}{*}{394} & \multirow{2}{*}{0,303} \\
\hline & & 6-10 yıl & 116 & 5,44 & 1,95 & & & \\
\hline \multirow{7}{*}{ 男 } & \multirow{2}{*}{ EDÖ-EU } & $0-5$ yıl & 280 & 15,73 & 14,61 & \multirow[t]{2}{*}{0,199} & \multirow[t]{2}{*}{394} & \multirow[t]{2}{*}{0,842} \\
\hline & & 6-10 yıl & 116 & 15,42 & 13,83 & & & \\
\hline & \multirow{2}{*}{ EDÖ-EA } & $0-5$ yıl & 280 & 2,63 & 2,63 & \multirow[t]{2}{*}{0,041} & \multirow[t]{2}{*}{394} & \multirow[t]{2}{*}{0,967} \\
\hline & & 6-10 yıl & 116 & 2,62 & 2,62 & & & \\
\hline & \multirow{2}{*}{ EDÖ-TOPLAM } & $0-5$ yıl & 280 & 25,13 & 25,13 & \multirow[t]{2}{*}{0,236} & \multirow[t]{2}{*}{394} & \multirow[t]{2}{*}{0,813} \\
\hline & & 6-10 yıl & 116 & 24,59 & 24,59 & & & \\
\hline & \multicolumn{8}{|c|}{$* p<.05, * * p<.001$} \\
\hline
\end{tabular}

AEDÖ: Alabama Ebeveyn Davranışları Ölçeği, AEDÖ-Çİ: Çocukla İlgilenme Alt Boyutu, AEDÖOE: Olumlu Ebeveynlik Alt Boyutu, AEDÖ-ZET: Zayıf Ebeveyn Takibi Alt Boyutu, AEDÖ-TD: Tutarsız Disiplin Alt Boyutu, AEDÖ-DC: Dayakla Cezalandırma Alt Boyutu, EDÖ: Evlilik Doyumu Ölçeği. 
Tablo 5 incelendiğinde ebeveynlerin AEDÖ'nin alt boyutlarından elde ettikleri puanlar arasında anlamlı bir fark olup olmadığını ortaya koymak adına yapılan İlişkisiz Örneklem T Testi sonuçlarına göre; ebeveynlerin, Çocukla İlgilenme [t(394) = 0,338, p> .05], Olumlu Ebeveynlik [t(394)=0,478, $\mathrm{p}<.05]$, Zayıf Ebeveyn Takibi [t(394) $=0,873, \mathrm{p}<.05]$, Tutarsız Disiplin [t(394)=0,930, $\mathrm{p}>.05]$ ve Dayakla Cezalandırma [t(394) $=0,303, \mathrm{p}>.05]$ alt boyutlarından elde ettikleri puan ortalamaları arasında anlamlı bir fark gözlenmemiştir.

Ebeveynlerin EDÖ-Evlilik Uyumu $[\mathrm{t}(394)=0,842, \mathrm{p}>.05]$, EDÖEbeveynlik Anlayışı $[\mathrm{t}(394)=0,967, \mathrm{p}>$.05] alt boyutları ve EDÖ-toplam $[\mathrm{t}(394)=0,813, \mathrm{p}>.05]$ elde ettikleri puanların ortalamaları arasında anlamlı bir fark gözlenmemiştir.

\section{Eğitim Düzeyine Göre Elde Edilen Bulgular}

Tablo 6. Alabama Ebeveyn Davranışları ve Evlilik Doyum Ölçeği Puanlarının Ebeveynin Eğitim Düzeyi Değişkenine Göre Farklılaşıp Farklılaşmadığını Belirlemek Üzere Yapılan İlişkisiz Örneklemler İçin Tek Yönlü Varyans Analizi (ANOVA) Sonuçları

\begin{tabular}{|c|c|c|c|c|c|c|c|c|c|c|c|c|}
\hline \multirow{2}{*}{\multicolumn{2}{|c|}{$\begin{array}{l}\text { Ölçekler ve Alt } \\
\text { boyutlar }\end{array}$}} & \multicolumn{2}{|c|}{$\begin{array}{c}\text { A } \\
\text { ilkokul } \\
\text { mezunu } \\
\mathrm{N}: 138\end{array}$} & \multicolumn{2}{|c|}{$\begin{array}{c}\text { B } \\
\text { Ortaokul } \\
\text { mezunu }\end{array}$} & \multicolumn{2}{|c|}{$\begin{array}{c}\mathrm{C} \\
\text { Lise } \\
\text { mezunu } \\
\mathrm{N}: 98\end{array}$} & \multicolumn{2}{|c|}{$\begin{array}{c}\text { D } \\
\text { Üniversite } \\
\text { ve Üzeri } \\
\text { mezun } \\
\mathrm{N}: 85\end{array}$} & \multirow[t]{2}{*}{$F$} & \multirow[t]{2}{*}{$p$} & \multirow[t]{2}{*}{$\begin{array}{l}\text { Anlamlı } \\
\text { Fark }\end{array}$} \\
\hline & & $\bar{x}$ & ss & $\bar{x}$ & ss & $\bar{x}$ & ss & $\bar{X}$ & ss & & & \\
\hline \multirow{5}{*}{ 省 } & AEDÖ-çi & 39 & 6,3 & 39 & 5,4 & 41 & 4,9 & 42 & 4,71 & 5 & $0,00^{*}$ & \multirow{5}{*}{$\begin{array}{l}A<D \\
B<D \\
A>C \\
A>D \\
A>C \\
A>D\end{array}$} \\
\hline & AEDÖ-OE & 25 & 3,8 & 26 & 3,3 & 26 & 3,4 & 26 & 2,75 & 1 & 0,39 & \\
\hline & AEDÖ-ZET & 18 & 7,2 & 16 & 5,3 & 16 & 5,8 & 15 & 4,95 & 3 & $0,03^{*}$ & \\
\hline & AEDÖ-TD & 16 & 3,5 & 16 & 4 & 15 & 3 & 15 & 3,7 & 2 & 0,19 & \\
\hline & AEDÖ-DC & 6 & 2,3 & 5 & 2 & 5 & 1,8 & 4,7 & 1,69 & 7 & $0,00^{*}$ & \\
\hline \multirow{3}{*}{$\begin{array}{l}\text { 罟: } \\
\text { : }\end{array}$} & EDÖ-EU & 18 & 15 & 15 & 13 & 15 & 15 & 14 & 13,3 & 3 & $0,03^{*}$ & \multirow{2}{*}{$A>D$} \\
\hline & EDÖ-EA & 3 & 2,6 & 3 & 2,4 & 3 & 2,7 & 2,2 & 2,13 & 1 & 0,29 & \\
\hline & $\begin{array}{l}\text { EDÖ- } \\
\text { TOPLAM }\end{array}$ & 29 & 23 & 24 & 18 & 24 & 21 & 20 & 18 & 3 & $0,02^{*}$ & $A>D$ \\
\hline \multicolumn{12}{|c|}{$* p<.05, * * p<.001$} & \\
\hline
\end{tabular}

AEDÖ: Alabama Ebeveyn Davranışları Ölçeği, AEDÖ-Çİ: Çocukla İlgilenme Alt Boyutu, AEDÖOE: Olumlu Ebeveynlik Alt Boyutu, AEDÖ-ZET: Zayıf Ebeveyn Takibi Alt Boyutu, AEDÖ-TD: Tutarsız Disiplin Alt Boyutu, AEDÖ-DC: Dayakla Cezalandırma Alt Boyutu, EDÖ: Evlilik Doyumu Ölçeği. 
Tablo 6 incelendiğinde ebeveynlerin AEDÖ’nin alt boyutlarından aldıkları puanlar arasında ebeveynin eğitim düzeyi değişkenine göre anlamlı bir fark olup olmadığına ilişkin yapılan İlişkisiz Örneklemler İçin Tek Yönlü Varyans Analizi (ANOVA) sonuçlarına göre, ebeveynlerin, Çocukla İlgilenme [F(3$396)=4,621, \mathrm{p}<.05]$, Zayıf Ebeveyn Takibi $[\mathrm{F}(3-396)=3,10, \mathrm{p}<.05]$ ve Dayakla Cezalandırma $[\mathrm{F}(3-396)=6,608, \mathrm{p}<.05]$ alt boyutlarından elde ettikleri puan ortalamaları arasında anlamlı bir fark gözlenmiştir. Üniversite ve üzeri programlardan mezun olan bireylerin çocukla ilgilenme puanı $(41,57)$, ilkokul mezunu bireylerin çocukla ilgilenme puanından $(39,17)$ ve ortaokul mezunu bireylerin çocukla ilgilenme puanından $(39,04)$ anlamlı düzeyde yüksek çıkmıştır. İlkokul mezunu bireylerin zayıf ebeveyn takibi davranışı puanı $(17,48)$ lise mezunu bireylerin $(15,45)$ ve üniversite mezunu bireylerin $(15,42)$ zayıf ebeveyn davranışı puanından yüksektir. Ortaokul mezunu bireylerin dayakla cezalandırma puanı $(5,27)$, lise mezunu bireylerin dayakla cezalandırma puanından $(4,93)$ ve üniversite mezunu bireylerin dayakla cezalandırma puanından $(4,74)$ anlamlı düzeyde yüksek çıkmıştır. Olumlu Ebeveynlik $[\mathrm{F}(3-396)=1,003, \mathrm{p}>.05]$ ve Tutarsız Disiplin $[\mathrm{F}(3-396)=$ $1,592, \mathrm{p}>.05$ ] alt boyutlarından elde ettikleri puanların ortalamaları arasında anlamlı bir fark gözlenmemiştir.

Ebeveynlerin EDÖ-Evlilik Uyumu $[\mathrm{F}(3-396)=3,10, \mathrm{p}<.05]$ alt boyutu ve EDÖ-toplam $[\mathrm{F}(3-396)=3,30, \mathrm{p}<.05]$ elde ettikleri puanların arasında anlamlı bir fark olduğu gözlenmiştir. Üniversite ve üzeri mezun olanların evlilik doyumu ve evlilik uyumu ilkokul mezunu olanlardan yüksek derecede anlamlı farklılık oluşturmuştur. EDÖ-Ebeveynlik Anlayışı $[\mathrm{F}(3-396)=1,30$, p> .05] alt boyutundan elde ettikleri puan ortalamaları arasında anlamlı bir fark gözlenmemiştir. 


\section{Evlenme Tarzına Göre Elde Edilen Bulgular}

Tablo 7. Alabama Ebeveyn Davranışları Ölçeği ve Evlilik Doyum Ölçeği Puanlarının Ebeveynin Evlenme Tarzı Değişkenine Göre Farklılaşıp Farklılaşmadığını Belirlemek Üzere Yapılan İlişkisiz Örneklem T Testi Sonuçları

\begin{tabular}{|c|c|c|c|c|c|c|c|c|}
\hline & $\begin{array}{l}\text { Ölçekler ve } \\
\text { Alt boyutlar }\end{array}$ & Gruplar & $N$ & $\bar{X}$ & SS & $t$ & $d f$ & $p$ \\
\hline \multirow{10}{*}{$\begin{array}{l}\text { 吕 } \\
\text { O: }\end{array}$} & \multirow[b]{2}{*}{ AEDÖ-Çi } & Görücü usulü & 252 & 39,3 & 5,77 & \multirow[b]{2}{*}{$-3,7$} & \multirow[b]{2}{*}{346} & \multirow[b]{2}{*}{$0,00 * *$} \\
\hline & & $\begin{array}{c}\text { Tanışıp } \\
\text { anlaşarak }\end{array}$ & 147 & 41,3 & 4,89 & & & \\
\hline & \multirow[b]{2}{*}{ AEDÖ-OE } & Görücü usulü & 252 & 25,3 & 3,57 & \multirow[b]{2}{*}{$-2,84$} & \multirow[b]{2}{*}{348} & \multirow[b]{2}{*}{$0,05^{*}$} \\
\hline & & $\begin{array}{c}\text { Tanışıp } \\
\text { anlaşarak }\end{array}$ & 147 & 26,3 & 2,99 & & & \\
\hline & \multirow[b]{2}{*}{ AEDÖ-ZET } & Görücü usulü & 252 & 16,9 & 6,53 & \multirow[b]{2}{*}{2,98} & \multirow[b]{2}{*}{364} & \multirow[b]{2}{*}{$0,03^{*}$} \\
\hline & & $\begin{array}{c}\text { Tanışıp } \\
\text { anlaşarak }\end{array}$ & 147 & 15,2 & 5,09 & & & \\
\hline & \multirow[b]{2}{*}{ AEDÖ-TD } & Görücü usulü & 252 & 15,8 & 3,63 & \multirow[b]{2}{*}{1,7} & \multirow[b]{2}{*}{397} & \multirow[b]{2}{*}{0,9} \\
\hline & & $\begin{array}{c}\text { Tanışıp } \\
\text { anlaşarak }\end{array}$ & 147 & 15,2 & 3,4 & & & \\
\hline & \multirow[b]{2}{*}{ AEDÖ-DC } & Görücü usulü & 252 & 5,46 & 2,16 & \multirow[b]{2}{*}{2,438} & \multirow[b]{2}{*}{348} & \multirow[b]{2}{*}{$0,015^{*}$} \\
\hline & & $\begin{array}{c}\text { Tanışıp } \\
\text { anlaşarak }\end{array}$ & 147 & 4,96 & 1,82 & & & \\
\hline \multirow{7}{*}{ ğ } & \multirow[b]{2}{*}{ EDÖ-EU } & Görücü usulü & 252 & 16,9 & 14,4 & \multirow[t]{2}{*}{2,289} & \multirow[t]{2}{*}{397} & \multirow[t]{2}{*}{$0,023^{*}$} \\
\hline & & $\begin{array}{c}\text { Tanışıp } \\
\text { anlaşarak }\end{array}$ & 147 & 15,4 & 13,9 & & & \\
\hline & \multirow[b]{2}{*}{ EDÖ-EA } & Görücü usulü & 252 & 2,84 & 2,57 & \multirow[t]{2}{*}{2,288} & \multirow[t]{2}{*}{329} & \multirow[t]{2}{*}{$0,023^{*}$} \\
\hline & & $\begin{array}{c}\text { Tanışıp } \\
\text { anlaşarak }\end{array}$ & 147 & 2,26 & 2,33 & & & \\
\hline & \multirow{2}{*}{$\begin{array}{l}\text { EDÖ- } \\
\text { TOPLAM }\end{array}$} & Görücü usulü & 252 & 27 & 20,8 & \multirow[t]{2}{*}{2,467} & \multirow[t]{2}{*}{397} & \multirow[t]{2}{*}{$0,014 *$} \\
\hline & & $\begin{array}{c}\text { Tanışıp } \\
\text { anlaşarak }\end{array}$ & 147 & 21,7 & 19,7 & & & \\
\hline & \multicolumn{8}{|c|}{$* p<.05, * * p<.001}$. \\
\hline
\end{tabular}

AEDÖ: Alabama Ebeveyn Davranışları Ölçeği, AEDÖ-Çİ: Çocukla İlgilenme Alt Boyutu, AEDÖOE: Olumlu Ebeveynlik Alt Boyutu, AEDÖ-ZET: Zayıf Ebeveyn Takibi Alt Boyutu, AEDÖ-TD: Tutarsız Disiplin Alt Boyutu, AEDÖ-DC: Dayakla Cezalandırma Alt Boyutu, EDÖ: Evlilik Doyumu Ölçeği. 
Tablo 7 incelendiğinde ebeveynlerin AEDÖ'nin alt boyutlarından elde ettikleri puanlar arasında anlamlı bir fark olup olmadığını ortaya koymak adına yapılan İlişkisiz Örneklem T Testi sonuçlarına göre; ebeveynlerin, Çocukla İlgilenme [t(346)= -3,701, $\mathrm{p}<.05]$, Olumlu Ebeveynlik [t(348)= -2,838, $\mathrm{p}<$ $.05]$, Zayıf Ebeveyn Takibi [t(364) $=2,98, \mathrm{p}<.05$ ] ve Dayakla Cezalandırma $[\mathrm{t}(348)=2,438, \mathrm{p}<.05]$ alt boyutlarından elde ettikleri puan ortalamaları arasında anlamlı bir fark gözlenmiştir. Tanışıp anlaşarak evlenen bireylerin çocukla ilgilenme puanı $(41,27)$ görücü usulü evlenen bireylerin çocukla ilgilenme puanından $(39,26)$ anlamlı düzeyde yüksek çıkmıştır. Tanışıp anlaşarak evlenen bireylerin olumlu ebeveynlik puanı $(26,26)$ görücü usulü evlenen bireylerin olumlu ebeveynlik puanından $(25,32)$ anlamlı düzeyde yüksek çıkmıştır. Görücü usulü evlenen bireylerin zayıf ebeveynlik takibi puanı $(16,90)$ tanışıp anlaşarak evlenen bireylerin zayıf ebeveynlik takibi puanından $(15,15)$ anlamlı düzeyde yüksek çıkmıştır. Görücü usulü evlenen bireylerin dayakla cezalandırma puanı $(5,46)$ tanışıp anlaşarak evlenen bireylerin dayakla cezalandırma puanından $(4,96)$ anlamlı düzeyde yüksek çıkmıştır. Tutarsız Disiplin [t(397)=1,7, p> .05] alt boyutunda elde ettikleri puan ortalaması arasında anlamlı bir fark gözlenmemiştir.

Ebeveynlerin EDÖ-Evlilik Uyumu $[\mathrm{t}(397)=2,289, \mathrm{p}<$.05] ve EDÖEbeveynlik Anlayışı $[\mathrm{t}(329)=2,288, \mathrm{p}<.05]$ alt boyutları ve EDÖ-toplam $[\mathrm{t}(347)=2,467, \mathrm{p}<.05]$ elde ettikleri puanlar arasında anlamlı bir fark olduğu gözlenmiştir. Tanışıp anlaşarak evlenen bireylerin evlilik doyumu, evlilik uyumu ve ebeveynlik anlayışı, görücü usulü evlenen ebeveynlerden yüksek düzeyde anlamlıdır. 


\section{Evlilik Süresine Göre Elde Edilen Bulgular}

Tablo 8. Alabama Ebeveyn Davranışları ve Evlilik Doyumu Ölçeği Puanlarının Ebeveynin Evlilik Süresi Değişkenine Göre Farklılaşıp Farklılaşmadığını Belirlemek Üzere Yapılan İlişkisiz Örneklemler İçin Tek Yönlü Varyans Analizi (ANOVA) Sonuçları

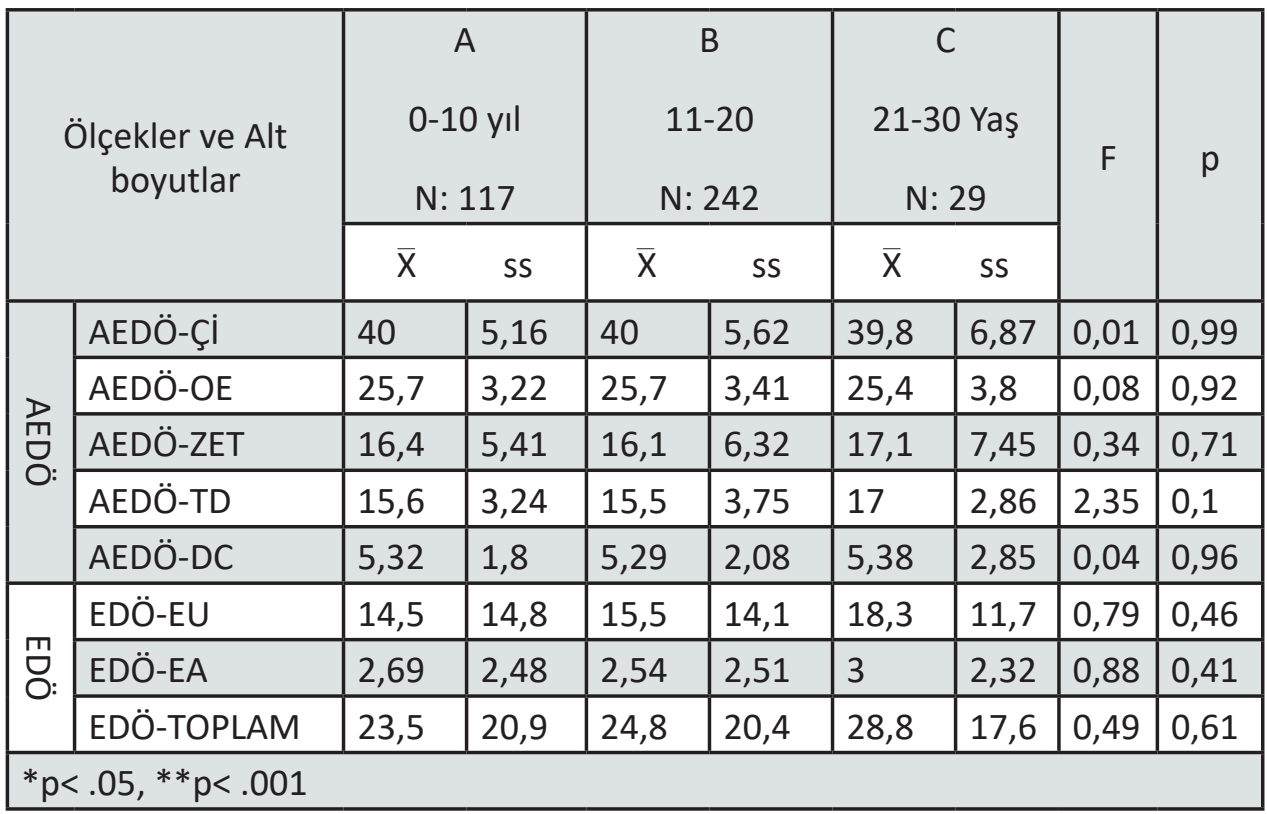

AEDÖ: Alabama Ebeveyn Davranışları Ölçeği, AEDÖ-Çİ: Çocukla İlgilenme Alt Boyutu, AEDÖOE: Olumlu Ebeveynlik Alt Boyutu, AEDÖ-ZET: Zayıf Ebeveyn Takibi Alt Boyutu, AEDÖ-TD: Tutarsız Disiplin Alt Boyutu, AEDÖ-DC: Dayakla Cezalandırma Alt Boyutu, EDÖ: Evlilik Doyumu Ölçeği.

Tablo 8 incelendiğinde ebeveynlerin AEDÖ'nin alt boyutlarından aldıkları puanlar arasında ebeveynin evlilik süresi değişkenine göre bir fark olup olmadığına ilişkin yapılan İlişkisiz Örneklemler İçin Tek Yönlü Varyans Analizi (ANOVA) sonuçlarına göre, ebeveynlerin Çocukla İlgilenme [F(2$385)=0,008, \mathrm{p}>.05]$, Olumlu Ebeveynlik $[\mathrm{F}(2-385)=0,083, \mathrm{p}>.05]$, Zayıf Ebeveyn Takibi $[\mathrm{F}(2-385)=0,342, \mathrm{p}>.05]$, Tutarsiz Disiplin $[\mathrm{F}(2-385)=2,349$, $\mathrm{p}>.05]$ ve Dayakla Cezalandırma $[\mathrm{F}(2-385)=0,036, \mathrm{p}>.05]$ alt boyutlarından elde ettikleri puanların ortalamaları arasında anlamlı bir fark gözlenmemiştir. 
Ebeveynlerin EDÖ-Evlilik Uyumu $[\mathrm{F}(2-385)=0,786$ p $>$.05] ve EDÖEbeveynlik Anlayışı $[\mathrm{F}(2-385)=0,883, \mathrm{p}>.05]$ alt boyutlar ve EDÖ-toplam $[\mathrm{F}(2-385)=0,493, \mathrm{p}>.05]$ elde ettikleri puanların ortalamaları arasında anlamlı bir fark gözlenmemiştir.

\section{Ebeveyn Davranıșları ve Evliliik Doyumuna Dair Elde Edilen Bulgular} Tablo 9. Ebeveyn Davranışlarının Kişilerin Evlilik Doyumları İle Olan İlişkisini Belirlemek Adına Yapılan Basit Doğrusal Korelasyon Analizi Sonuçları

\begin{tabular}{|c|c|c|c|c|c|c|c|c|}
\hline & $\begin{array}{l}\text { 1.EDÖ- } \\
\text { Toplam }\end{array}$ & $\begin{array}{l}\text { 2.EDÖ- } \\
\text { EU }\end{array}$ & $\begin{array}{l}\text { 3.EDÖ- } \\
\text { EA }\end{array}$ & $\begin{array}{l}\text { 4.AEDÖ- } \\
\text { çi }\end{array}$ & $\begin{array}{l}\text { 5.AEDÖ- } \\
\text { OE }\end{array}$ & $\begin{array}{l}\text { 6.AEDÖ- } \\
\text { TD }\end{array}$ & $\begin{array}{l}\text { 7.AEDÖ- } \\
\text { ZET }\end{array}$ & $\begin{array}{l}\text { 8.AEDÖ- } \\
\text { DC }\end{array}$ \\
\hline $\begin{array}{l}\text { 1.EDÖ- } \\
\text { Toplam }\end{array}$ & 1 & $0,978 * *$ & $0,726^{* *}$ & $-0,315^{* *}$ & $-0,266 * *$ & $0,110^{*}$ & $0,248^{*}$ & $0,365^{* *}$ \\
\hline $\begin{array}{l}\text { 2. EDÖ- } \\
\text { EU }\end{array}$ & & 1 & $0,644 * *$ & $-0,306 * *$ & $-0,242^{* *}$ & $0,106 *$ & $0,225^{* *}$ & $0,340 * *$ \\
\hline $\begin{array}{l}\text { 3. EDÖ- } \\
\text { EA }\end{array}$ & & & 1 & $-0,263 * *$ & $-0,241 * *$ & $0,109 *$ & $0,198 * *$ & $0,292 * *$ \\
\hline $\begin{array}{l}\text { 4. AEDÖ- } \\
\text { çi }\end{array}$ & & & & 1 & $0,655^{* *}$ & $-0,071$ & $-0,445^{* *}$ & $-0,368 * *$ \\
\hline $\begin{array}{l}\text { 5. AEDÖ- } \\
\text { OE }\end{array}$ & & & & & 1 & $-0,028$ & $-0,408 * *$ & $-0,244 * *$ \\
\hline $\begin{array}{l}\text { 6. AEDÖ- } \\
\text { TD }\end{array}$ & & & & & & 1 & $0,274 * *$ & $0,142 * *$ \\
\hline $\begin{array}{l}\text { 7. AEDÖ- } \\
\text { ZET }\end{array}$ & & & & & & & 1 & $0,443 * *$ \\
\hline $\begin{array}{l}\text { 8. AEDÖ- } \\
\text { DC }\end{array}$ & & & & & & & & 1 \\
\hline
\end{tabular}

AEDÖ: Alabama Ebeveyn Davranışları Ölçeği, AEDÖ-Çİ: Çocukla İlgilenme Alt Boyutu, AEDÖOE: Olumlu Ebeveynlik Alt Boyutu, AEDÖ-ZET: Zayıf Ebeveyn Takibi Alt Boyutu, AEDÖ-TD: Tutarsız Disiplin Alt Boyutu, AEDÖ-DC: Dayakla Cezalandırma Alt Boyutu, EDÖ: Evlilik Doyumu Ölçeği.

Tablo 9'da ebeveyn davranışları ile kişilerin evlilik doyumları arasında bir ilişkinin olup olmadığını belirlemek amacıyla yapılan basit doğrusal korelasyon işlemine göre, EDÖ toplam puanları ile AEDÖ-Çİ $(r=-0,315, p<$ $0,001)$ ve AEDÖ-OE $(r=-0,266, p<0,001)$ arasında negatif yönde ve anlamli; AEDÖ-TD $(r=0,110, p<0,05)$, AEDÖ-ZET $(r=0,248, p<0,05)$ ve AEDÖ$\mathrm{DC}(\mathrm{r}=0,365, \mathrm{p}<0,001)$ arasında pozitif yönde ve anlamlı bir ilişki olduğu gözlenmektedir. Basit doğrusal korelasyon işlemine göre; Evlilik Doyumu 
arttıkça Çocukla İlgilenme ve Olumlu Ebeveynlik davranışları artmaktadır. Evlilik Doyumu azaldıkça Zayıf Ebeveyn Takibi, Tutarsız Disiplin ve Dayakla Cezalandırma davranışları artmaktadır.

EDÖ- EU alt boyutu puanları ile AEDÖ-Çİ $(\mathrm{r}=-0,306, \mathrm{p}<0,001)$ ve AEDÖOE $(r=-0,242, p<0,001)$ arasinda negatif yönde ve anlamli; AEDÖ-TD ( $r=$ $0,106, \mathrm{p}<0,05)$, AEDÖ-ZET $(\mathrm{r}=0,225, \mathrm{p}<0,001)$ ve AEDÖ-DC $(\mathrm{r}=0,340, \mathrm{p}<$ $0,001)$ arasında pozitif yönde ve anlamlı bir ilişki olduğu gözlenmektedir. Basit doğrusal korelasyon işlemine göre Evlilik Uyumu arttıkça Çocukla İlgilenme ve Olumlu Ebeveynlik davranışları artmaktadır. Evlilik Uyumu azaldıkça Zayıf Ebeveyn Takibi, Tutarsız Disiplin ve Dayakla Cezalandırma davranışları artmaktadır.

EDÖ-EA alt boyutu puanları ile AEDÖ-ÇI $(r=-0,263$, p< 0,001) ve AEDÖOE $(r=-0,241, p<0,001)$ arasinda negatif yönde ve anlamli; AEDÖ-TD ( $r=$ $0,109, \mathrm{p}<0,05)$, AEDÖ-ZET $(\mathrm{r}=0,198, \mathrm{p}<0,001)$ ve AEDÖ-DC $(\mathrm{r}=0,292$, $\mathrm{p}<0,001)$ arasında pozitif yönde ve anlamlı bir ilişki olduğu gözlenmektedir. Basit doğrusal korelasyon işlemine göre Ebeveynlik Anlayışı arttıkça Çocukla İlgilenme ve Olumlu Ebeveynlik davranışları artmaktadır. Ebeveynlik Anlayışı azaldıkça Zayıf Ebeveyn Takibi, Tutarsız Disiplin ve Dayakla Cezalandırma davranışları artmaktadır.

\section{SONUÇLAR}

\section{Ebeveyn Davranışlarının Sosyodemografik Değişkenlere Göre}

\section{Sonuçları}

1. Ebeveyn davranışlarından Çocukla İlgilenme ve Zayıf Ebeveyn Takibi anne ve baba olma durumuna göre anlamlı olarak farklılaşmaktadır. Annelerin çocukla ilgilenme davranışı babalardan daha fazla, babaların zayıf ebeveyn davranışı annelerden daha fazladır. Olumlu Ebeveynlik, Tutarsız Disiplin ve Dayakla Ceza anne ve baba olma durumuna göre anlamlı olarak farklılaşmamaktadır.

2. Ebeveyn davranışlarının 5 alt boyutunda da anne babaların yaş değişkeni anlamlı olarak farklılaşmamaktadır.

3. Ebeveyn davranışlarının 5 alt boyutunda da anne babalar arasındaki yaş farkı değişkeni anlamlı olarak farklılaşmamaktadır. 
4. Ebeveyn davranışlarından Çocukla İlgilenme, Zayıf Ebeveyn Takibi ve Dayakla Ceza davranışları eğitim düzeyi değişkenine göre anlamlı olarak farklılaşmaktadır. Üniversite ve üzeri programlardan mezun olan bireylerin çocukla ilgilenme davranışı, ilkokul mezunu bireylerin çocukla ilgilenme davranışından ve ortaokul mezunu bireylerin çocukla ilgilenme davranışından anlamlı düzeyde yüksek çıkmıştır. İlkokul mezunu bireylerin zayıf ebeveyn takibi davranışı lise mezunu bireylerin ve üniversite mezunu bireylerin zayıf ebeveyn davranışından yüksektir. Ortaokul mezunu bireylerin dayakla cezalandırma davranışı, lise mezunu bireylerin dayakla cezalandırma davranışından ve üniversite mezunu bireylerin dayakla cezalandırma davranışından anlamlı düzeyde yüksek çıkmıştır. Olumlu Ebeveynlik ve Tutarsız Disiplin davranışları eğitim düzeyi değişkenine göre anlamlı olarak farklılaşmamaktadır.

5. Ebeveyn davranışlarından Çocukla İlgilenme, Olumlu Ebeveynlik, Zayıf Ebeveyn Takibi ve Dayakla Ceza evlilik tarzı değişkenine göre anlamlı olarak farklılaşmaktadır. Tanışıp anlaşarak evlenen bireylerin çocukla ilgilenme ve olumlu ebeveyn davranışları görücü usulü evlenen bireylerin çocukla ilgilenme ve olumlu ebeveyn davranışlarından anlamlı düzeyde yüksek çıkmıştır. Görücü usulü evlenen bireylerin zayıf ebeveyn takibi ve dayakla cezalandırma davranışları tanışıp anlaşarak evlenen bireylerin zayıf ebeveyn takibi ve dayakla cezalandırma davranışlarından anlamlı düzeyde yüksek çıkmıştır. Tutarsız Disiplin davranışı evlilik tarzı değişkenine göre anlamlı olarak farklılaşmamaktadır.

6. Ebeveyn davranışlarının 5 alt boyutunda da evlilik süresi değişkeni anlamlı olarak farklılaşmamaktadır.

\section{Evlilik Doyumunun Sosyo-Demografik Değişkenlere Göre Sonuçları}

1. Evlilik Doyumunun alt boyutu olan Ebeveynlik Anlayışı anne ve baba olma durumuna göre anlamlı olarak farklılaşmaktadır. Babaların ebeveynlik anlayışı annelerden yüksektir. Evlilik doyumu ve Evlilik Uyumu alt boyutu anne ve baba olma durumuna göre anlamlı olarak farklılaşmamaktadır.

2. Evlilik Doyumunun alt boyutu olan Evlilik Uyumu ve Ebeveynlik Anlayışı ile Evlilik Doyumu anne babaların yaş değişkenine göre anlamlı olarak farklılaşmamaktadır. 
3. Evlilik Doyumunun alt boyutları olan Evlilik Uyumu ve Ebeveynlik Anlayışı ile Evlilik Doyumu bireylerin eşleri arasındaki yaş farkı değişkenine göre anlamlı olarak farklılaşmamaktadır.

4. Evlilik Doyumunun alt boyutu olan Evlilik Uyumu ve Evlilik doyumu bireylerin eğitim düzeyi değişkenine göre anlamlı olarak farklılaşmaktadır. Üniversite mezunu bireylerin evlilik doyumu ve evlilik uyumu ilkokul mezunlarının evlilik doyumu ve evlilik uyumundan daha yüksektir. Ebeveynlik Anlayışı alt boyutu bireylerin eğitim düzeyi değişkenine durumuna göre anlamlı olarak farklılaşmamaktadır.

5. Evlilik Doyumu, Evlilik Uyumu ve Ebeveynlik Anlayışı evlilik tarzı değişkenine göre anlamlı olarak farklılaşmaktadır. Tanışarak ve anlaşarak evlenen bireylerin evlilik doyumu evlilik uyumu ve ebeveynlik anlayışı görücü usulü evlenen bireylerin evlilik doyumu, evlilik uyumu ve ebeveynlik anlayışından anlamlı düzeyde yüksektir.

6. Evlilik Doyumunun alt boyutu olan Evlilik Uyumu ve Ebeveynlik Anlayışı ile Evlilik Doyumu evlilik süresi değişkenine göre anlamlı olarak farklılaşmamaktadır.

\section{Ebeveyn Davranıșlarının Evlilik Doyumu İle Arasındaki İlișkinin} Sonuçları

Ebeveyn davranışlarının olumlu boyutları olan Çocukla İlgilenme ve Olumlu Ebeveynlik davranışları evlilik doyumu ile pozitif yönde anlamlı ilişkili, ebeveyn davranışlarının olumsuz boyutları olan Zayıf Ebeveyn Takibi, Tutarsız Disiplin ve Dayakla Cezalandırma davranışları ile evlilik doyumu negatif yönde anlamlı ilişkilidir.

\section{TARTISSMA VE YORUM}

\section{Cinsiyete Göre Bulguların Tartıșılması}

Anne babaların Ebeveyn Davranışları alt ölçeklerinden Çocukla İlgilenme ve Zayıf Ebeveyn Takibi alt boyutları cinsiyete göre farklılaşmaktadır. Fakat Olumlu Ebeveynlik, Tutarsız Disiplin ve Dayakla Cezalandırma alt boyutları cinsiyete göre farklılaşmamaktadır. Anneler babalara göre daha fazla çocukla ilgilenme davranışı sergilemektedir. Babalar ise annelere göre daha fazla zayıf ebeveyn takibi davranışı göstermektedir. Araştırma sonucunu destekleyen 
çalışmalar mevcuttur. Vazquez ve ark. (2019) Meksika popülasyonunda kadınların çocukla ilgilenme ve olumlu ebeveynlik davranışlarının erkeklerden fazla olduğu sonucuna ulaşmıştır. Robert (2009) kadınların olumlu ebeveynlik davranışının erkeklerden anlamlı olarak daha yüksek olduğu sonucuna ulaşmıştır. Erkekler için üç olumsuz alt ölçeğin (Zayıf Ebeveyn Takibi, Tutarsız Disiplin ve Dayakla Cezalandırma) hepsinde puanlar daha yüksek çıkmıştır. Benzer şekilde, ikinci pozitif alt boyut olan Çocukla ilgilenme davranışı kadınlarda erkeklere göre daha yüksektir ancak anlamlı düzeyde değildir. Escribano ve ark. (2013) İspanyol çocukların üzerinde APQ Alabama Ebeveyn Davranışları Ölçeği nin psikometrik özelliklerini ve faktör yapısını analiz etmeyi amaçlamıştır. Çalışmasında cinsiyet farklılıklarının ebeveyn davranışları ile anlamlı farklılığı bulunmamıştır. Sadece erkekler 'Zayıf ebeveyn Takibi' alt boyutunda kadınlardan yüksek puan almıştır. Servera ve ark. (2015) çalışmanın amacı Alabama Ebeveyn Davranışları Ölçeğini İtalyan nüfusuna uyarlama çalışmasıdır. Babalar ve anneler arasında negatif ebeveyn davranışları açısından bir fark yoktur, ancak olumlu ebeveynlikte annelerin puanları daha yüksektir. Benedetto ve Ingrassia (2015) evlilikteki çatışma biçimleri ve ebeveyn davranışları ebeveynin cinsiyetine bağlı olarak değişmektedir. Anneler için yıkıcı çatışma biçimleri (şiddet ve saldırganlık) Alabama Ebeveyn Davranışları Ölçeğinin alt boyutu Çocukla İlgilenme ve Olumlu Ebeveynlik ile negatif yönde, Tutarsız Disiplin alt boyutu ile pozitif yönde ilişkilidir. Babalar için uzlaşma, kaçınma ve saldırı, Çocukla İlgilenme ve Olumlu Ebeveynlik ile olumlu yönde ilişkilidir. Araştırmanın desteklenmediği çalışmalar daha azdır. Mazefsky ve Farrell (2005) çalışmasında ebeveyn davranışlarının kadınlar ve erkekler üzerinde anlamlı ilişkisi bulunmamıştır.

Türkiye'de bu ölçeğin uyarlama çalışması yeni olduğundan yurt içinde karşılaştırma ve atıf yapılacak bir araştırma yoktur. Yurt dışında da çalışmanın çıkan sonucu destekleyen ve desteklemeyen örnekler verilmiştir. Annelerin çocukla ilgilenme davranışlarının babalardan yüksek çıkmasının sebebi, kadın popülasyonunun çoğunluğunun çalışmaması olabilir. Büyük çoğunluğu çalışmayan popülasyonun çocuğuyla ilgilenme, çocuğun ihtiyaçlarını giderme ve çocuğun problem yaşadığı durumda hemen ilk müdahaleyi kendisinin yapacak uygun ortam ve koşulların olması çocukla ilgilenme davranışlarının annelerde yüksek çıkmasının sebebi olabilir. Ayrıca çalışan annelerde de 
çocukla ilgilenmenin annenin ana görevi olduğu toplumsal baskısı annenin çalışsa dahi çocukla ilgilenme davranışının yüksek olması sebeplerinden olabilir. Birey yaşama gelince ilk bilgileri ailesinden özellikle de annesinden alır. Anne, çocuğun yol göstericisi ve ona ışık tutanıdır ve anne davranışlarını karşıllk beklemeden doğal sevgisiyle yapar. Annenin çocuğun üzerinde olan büyük etkisi de buradan kaynaklanır. Babanın sevgisini ise ilkeler ve umutlar belirler (Çiftçi, 1991). Anne babanın çocuğa olan bakış açıları da çocukla ilgilenme davranışlarının annelerde yüksek çıkmasının sebebi olabilir. Babaların annelere göre daha yüksek düzeyde zayıf ebeveyn takibi sergileme sebebi, yukarıdaki açıklamalara benzer şekilde, baba çalışan ve günün çoğunu işte geçiren ebeveyndir. Çocukla ilgilenmeye zamanının olmaması söz konusu olabilir. Ayrıca babaların ev içindeki durumlardan daha az haberi olmalı toplumsal normu da babaların çocuklarının yaptıklarından habersiz olmalarının ve çocuğun takibinin yetersiz olmasının sebebi olabilir.

Evlilik doyumu alt boyutlarının anne ve baba açısından incelendiğinde: babaların ebeveynlik anlayışı annelerin ebeveynlik anlayışından anlamlı şekilde yüksek çıkmıştır. Evlilik doyumu toplam puanı, evlilik uyumu alt boyutu cinsiyete göre farklılık göstermemektedir. Literatürde çalışmayı destekleyen çalışmalar mevcuttur: Çıtışlı Turgut (2018), Uçar (2018), Yanar Güngör (2019), Altun (2015), Çelik (2006), Çavuşoğlu (2011), Berk (2009), Güven (2005), Çağ ve Yıldırım (2013), Yıldız (2018), Sarı (2012), Taşköprü (2013), Demiray (2006), Erden (2016), Döner (2015), Turanlı (2010), Özaydınlık (2014), Kılıç (2017), Bildirici (2016) çalışmalarında kadın ve erkeklerin evlilik doyumu arasında farklılık gözlenmemiştir. Bu durumun tam tersi sonuçlar da mevcuttur: Tozan (2018), Aktürk (2006) ve Çınar (2008),Çağ (2011), Şentürk (2018) araştırmasında evlilik doyumu cinsiyete göre farklılaşmaktadır ve erkeklerin evlilik doyumu kadınlarınkinden fazladır. Ebeveynlik anlayışı alt boyutu ebeveynlerin çocuk yetiştirmeye dair sorumluluklardan kaynaklanan anlaşmazlıkları ve bunların ilişkiye yansımasını ölçmektedir (Canel, 2007). Babaların ebeveynlik anlayışının annelerden fazla olması, babaların annelere göre çocuk yetiştirmede sorumluluk aldıklarına dair inançlarının olduğunu, çocuklarla iletişiminin yeterli olarak algılandığını ve çocuk yetiştirirken anlaşmazlıkların daha az olduğu şeklinde yorumlanabilir. Erkekler baba olmanın kendilerini daha çok olgunlaştıracağına ve sorumluluk sahibi 
yapacağına inanırlar (İşmen Gazioğlu, 2017). Bu durumdan da dolayı babaların ebeveynlik anlayışı annelerden yüksek çıkmış olabilir.

\section{Yaşa Göre Bulguların Tartışıllması}

Anne babaların Ebeveyn Davranışları alt boyutları: Çocukla İlgilenme, Olumlu Ebeveynlik, Zayıf Ebeveyn Takibi, Tutarsız Disiplin ve Dayakla Cezalandırma davranışları ebeveynlerin yaşına göre anlamlı farklılık göstermemektedir. Eminoğlu (2007) 4-5 yaş çocukların sosyal davranışları ile ebeveynlerin davranışları arasındaki ilişkiyi incelemiştir. Annelerin ayrıcalıklardan yoksunlaştırma alt boyutunda yaşa göre anlamlı fark bulunurken, babaların amaçlara ulaşmada yardımcı olma, tutarlı disiplin ve başarı için baskı boyutlarında yaşa göre anlamlı farklılık çıkmıştır. Anne babaların ebeveyn davranışlarının yaşa göre farklılık göstermeme sebebi, anne babaların yaşlarının ilerlemesine rağmen çocuklarına sergiledikleri ebeveyn davranışları benzerlik gösteriyor olabilir.

Evlilik doyumu ve alt boyutları açısından incelendiğinde Anne babaların Evlilik Doyumu toplam puanı, Evlilik Uyumu ve Ebeveynlik Anlayışı alt boyutları ebeveynlerin yaşına göre anlamlı bir fark göstermemektedir. Literatürde bu durumu destekleyen ve desteklemeyen çalışmalar mevcuttur. Şentürk (2018), Güven (2005), Berk (2009), Uçar (2018), Altun (2015), Çınar (2008), Çağ (2011), Yıldız (2013), Gürsoy (2004), Turanlı (2010), Kılıç (2017) çalışmasında yaş değişkeninin evlilik doyumunu yordamadığı sonucuna varmıştır. Tezer (1994), Tozan (2018), Yıldız (2018), Öztahtacı (2017), Taşköprü (2013),Demiray (2006), Özaydınlık (2014) ve Bildirici (2016) çalışmalarında yaş ilerledikçe evlilik doyumunun arttığını bulmuştur. Anne babaların kaç yaşında oldukları evlilik süresi değişkeninden bağımsız analiz edilmesi anlamlı farklılık çıkmamasının sebebi olabilir.

\section{Eşlerin Arasındaki Yaş Farkı Değişkenine Göre Bulgulların Tartışıllması}

Anne babaların Ebeveyn Davranışları alt boyutları: Çocukla İlgilenme, Olumlu Ebeveynlik, Zayıf Ebeveyn Takibi, Tutarsız Disiplin ve Dayakla Cezalandırma eşler arasındaki yaş farkına göre anlamlı farklılık göstermemektedir. Literatürde ebeveyn davranışları ile eşler arasındaki yaş farkını çalışan araştırmaya rastlanmamıştır. 
Evlilik doyumu ve alt boyutları yaş farkı açısından incelendiğinde Evlilik Doyumu toplam puanı, Evlilik Uyumu ve Ebeveynlik Anlayışı alt boyutları eşlerin arasındaki yaş farkına göre anlamlı bir fark bulunmamıştır. Literatürde bu çalışmayı doğrulayan çalışmalar mevcuttur. Çağ (2011), Çağ ve Yıldırım (2013), Kılıç (2017) yaptığı çalışmada evli bireylerin eşleri arasındaki yaş farkının evlilik doyumunu yordamadığı sonucuna varılmıştır. Erden (2016) ise eşler arasındaki yaş farkı ile evlilik doyumu arasında negatif yönlü bir korelasyon olmasına rağmen bu ilişkinin anlamlı olmadığını bulmuştur. Ovalı (2010) farklı coğrafi bölgelerde yaşayan bireylerin evlilik çatışmalarının demografik özelliklere göre farklılaşıp farklılaşmadığını araştırdığı çalışmasında, eşler arasındaki yaş farkının artmasının çatışmaların artmasına sebep olduğu sonucuna ulaşmıştır. Yaş farkının fazla olması aile yaşam döngüsünde bulundukları aşamayı, hayata bakış açılarını etkileyeceğinden eşlerin uyumunu zorlaştırabilecek etmen olarak değerlendirilebilir (Günayer Şenel, 2017). Evlilik doyumunun eşlerin arasındaki yaş farkına göre farklılaşmaması eşler arasındaki yaş farkı ne olursa olsun bireyler evliliklerinden benzer düzeylerde doyum almakta ve evliliklerinden doyum istemektedirler. Önemli olan yaş farkı değil, eşlerin birbiriyle anlaşması ve iletişim kurmaları olabilir.

\section{Eğitim Düizeyi Değişkenine Göre Bulguların Tartışıllması}

Anne babaların Ebeveyn Davranışları alt ölçeklerinden Çocukla İlgilenme, Dayakla Cezalandırma ve Zayıf Ebeveyn Takibi alt boyutları eğitim düzeyi değişkenine göre anlamlı şekilde farklılaşmaktadır. Üniversite ve üzeri programlardan mezun olan bireylerin çocukla ilgilenme davranışı, ilkokul ve ortaokul mezunu bireylerin çocukla ilgilenme davranışından anlamlı düzeyde yüksek çıkmıştır. İlkokul mezunu bireylerin zayıf ebeveyn takibi davranışı lise mezunu bireylerin ve üniversite mezunu bireylerin zayıf ebeveyn takibi davranışından yüksektir. Ortaokul mezunu bireylerin dayakla cezalandırma davranışı, lise ve üniversite mezunu bireylerin dayakla cezalandırma davranışından anlamlı düzeyde yüksek çımıştır. Fakat Olumlu Ebeveynlik ve Tutarsız Disiplin alt boyutları eğitim düzeyi değişkenine göre farklılaşmamaktadır. Badahdah ve Le (2016) ebeveynlerin eğitim düzeyinin Alabama Ebeveyn Davranışları Ölçeği üzerindeki etkisini incelenmiştir. Ebeveynleri iki gruba ayrılmıştır: lisans derecesine sahip ebeveynler (\% 42.5) 
ve bir üniversite derecesinden düşük ebeveynler (\% 57.5). Lisans Derecesi veya daha yüksek olan ebeveynlerin, Lisans derecesinden daha düşük eğitim düzeyindeki anne-babalardan Dayakla Ceza ve Tutarsız Disiplin alt boyutlarını daha az uyguladığı bulunmuştur. Elgar ve ark (2007) araştırmasında anne babanın eğitim düzeyi ile ebeveyn davranışları arasında farklılık bulunmamıştır. Hawess ve Dadds (2006) çalışmasında ebeveyn davranışları ile eğitim düzeyi arasında anlamlı farklılık bulunmamıştır.

Üniversite ve üzeri programlardan mezun olan bireylerin çocukla ilgilenme davranışının, ilkokul ve ortaokul mezunu bireylerin çocukla ilgilenme davranışından anlamlı düzeyde yüksek çıkmasının sebebi, belirli düzeyde eğitim almış kişilerin çocuklarının ihtiyaçlarını görmede ve anlamada daha olgun oldukları ve çocuklarının ihtiyaçlarına cevap vermek için kendilerini geliştirmeye açık görüşe sahip olmalarından kaynaklanıyor olabilir. İlkokul mezunu bireylerin zayıf ebeveyn takibi davranışının lise mezunu ve üniversite mezunu bireylerin zayıf ebeveyn davranışından yüksek olmasının sebebi, ebeveynlerin eğitim düzeyi arttıkça çocuklarının takibine yönelik davranışların daha önemli olduğunu düşünmeleri etkili olabilir. Ortaokul mezunu bireylerin dayakla cezalandırma davranışının, lise mezunu ve üniversite mezunu bireylerin dayakla cezalandırma davranışından yüksek çıkmasının sebebi, eğitim seviyesinin arttıkça bireylerin olumlu disiplin yöntemlerini uygulamayı tercih etmeleri olabilir.

Ebeveynlerin evlilik doyumu ve alt ölçeklerine bakıldığında, anne babaların Evlilik Doyumu ölçeği Ebeveynlik Anlayışı alt boyutunda eğitim düzeyi değişkenine göre anlamlı bir fark bulunmamıştır. Evlilik Doyumu toplam puanı ve Evlilik Uyumu alt boyutları eğitim düzeyi değişkenine göre anlamlı bir farklık göstermektedir. Üniversite mezunu bireylerin evlilik doyumu ve evlilik uyumu ilkokul mezunlarının evlilik doyumu ve evlilik uyumundan daha yüksektir. Literatürdeki eğitim düzeyi değişkeni ile yapılan çok sayıda çalışma mevcuttur. Gürsoy (2004) çalışmasında kadınların eğitim düzeyi arttıkça evlilik uyumunun yükseldiği sonucuna ulaşmıştır. Özaydınlık (2014) ve Bildirici (2016) Evli çiftlerin eğitim düzeyi arttıkça evlilik uyumu artmaktadır. Yanar Güngör (2019)'ün çalışmasında eğitim seviyesinde lisans mezunu evli bireylerin evlilik doyumunun, ön lisans mezunu evli bireylerin evlilik doyumundan anlamlı bir şekilde yüksek olduğunu ortaya koyulmuştur. 
Tozan (2018), Şentürk (2018), Altun (2015), Çınar (2008), Çelik (2006), Çavuşoğlu (2011), Çağ (2011), Öztahtacı (2017), Taşköprü (2013), Turanlı (2010), Kılıç (2017) çalışmasında eğitim durumu evlilik doyumu üzerinde farklılık yaratmamıştır. Üniversite mezunu bireylerin evlilik doyumu ve evlilik uyumu ilkokul mezunlarının evlilik doyumu ve evlilik uyumundan daha yüksek olmasının sebebi, eğitim düzeyi arttıkça eşlerin sağlıklı iletişim kurması ve ben dilini doğru kullanması, birbirlerini daha iyi anlamaları, evlilikle ilgili karşılaştıkları sorunları yapıcı şekilde alternatif yollarla çözebilmeleri ve uzlaşma sağlayabilmelerinden kaynaklanıyor olabilir. Eğitim seviyesiyle birlikte daha farkındalığa sahip bir düşünce yapısına sahip olan bireyler evliliklerinde yardım arama ve çözüm arayışına girme çabasında olduğundan kaynaklanabilir.

\section{Evlilik Tarzı Değişkenine Göre Bulguların Tartışıllması}

Anne babaların Ebeveyn Davranışları alt ölçeklerinden Çocukla İlgilenme, Olumlu Ebeveynlik, Zayıf Ebeveyn Takibi ve Dayakla Cezalandırma alt boyutları evlilik tarzı değişkenine göre anlamlı şekilde farklılaşmaktadır. Tanışıp anlaşarak evlenen bireylerin çocukla ilgilenme ve olumlu ebeveynlik davranışları görücü usulü evlenen bireylerin çocukla ilgilenme ve olumlu ebeveynlik davranışlarından anlamlı düzeyde yüksek çımıştır. Görücü usulü evlenen bireylerin zayıf ebeveyn takibi ve dayakla cezalandırma davranışları tanışıp anlaşarak evlenen bireylerin zayıf ebeveyn takibi ve dayakla cezalandırma davranışlarından anlamlı düzeyde yüksek çıkmıştır. Fakat Tutarsız Disiplin davranışı evlilik tarzı değişkenine göre farklılaşmamaktadır. Tanışıp anlaşarak evlenen bireylerin çocukla ilgilenme ve olumlu ebeveynlik davranışı görücü usulü evlenen bireylerin çocukla ilgilenme ve olumlu ebeveynlik davranışından anlamlı düzeyde yüksek çımasının sebebi, tanışıp anlaşarak evlenen bireyler kendilerinin seçtiği ve zaman içerisinde kişilik özelliklerini, huylarını tanıdığı bireyler ile evlenmektedir. Ortak anlayış ve görüşe sahip olmasalar bile birbirlerinin özelliklerini çözüp önceden önlem almış ve kuralları beraber koyup çocuk yetiştirmeye dair fikir birliğinde olmuş olabilirler. Görücü usulü evlenen bireylerin zayıf ebeveyn takibi ve dayakla cezalandırma davranışlarının tanışıp anlaşarak evlenen bireylerin zayıf ebeveyn takibi ve dayakla cezalandırma davranışından anlamlı düzeyde 
yüksek çıkmasının sebebi, aileleri aracılığıyla evlenen bireylerin birbirlerini görece az tanımaları ve çocuklarına dair uygulamaya konulacak davranışlar ve stillerin farklılık göstermesi neden olmuş olabilir.

Ebeveynlerin evlilik doyumu ve alt boyutlarına bakacak olursak, anne babaların Evlilik Doyumu, evlilik uyumu ve ebeveynlik anlayışları ile evlilik tarzı değişkenine göre anlamlı olarak farklılaşmaktadır. Tanışıp anlaşarak evlenen bireylerin evlilik doyumu, evlilik uyumu ve ebeveynlik anlayışları görücü usulü evlenen bireylerin evlilik doyumu, evlilik uyumu ve ebeveynlik anlayışlarından anlamlı düzeyde yüksek çıkmıştır. Yanar Güngör (2019) evlenme biçimine göre aşk evliliği yapan evli bireylerin evlilik doyumunun mantık evliliği ve görücü usulüyle evlenenlerin evlilik doyumundan anlamlı bir şekilde yüksek olduğunu bulunmuştur. Uçar (2018) evlilik doyumu ölçeğinin alt boyutları olan; evlilik uyumu, öfke, eşin ailesiyle iletişim ve ekonomik anlayış boyutları puanları eşle tarzına göre anlamlı farklılık yaratmamaktadır. Ylldız (2013), Bildirici (2016) ve Özaydınlık (2014) anlaşarak, kendi karar vererek evlenenlerin görücü usulü ile evlenenlere göre evlilik doyumu daha yüksek bulunmuştur. Altun (2015), Berk (2009), Çağ (2011), Yıldız (2018), Öztahtac1 (2017), Demiray (2006), Döner (2015), Polat (2006), Gürsoy (2004), Kılıç (2017), Kublay ve Oktan (2015) çalışmalarında evlilik tarzının evlilik doyumu ile ilişkili olmadıklarını bulmuştur. Tanışarak ve anlaşarak evlenen bireylerin evlilik doyumu ve evlilik uyumu, görücü usulü evlenen bireylerin evlilik doyumu ve evlilik uyumundan anlamı düzeyde yüksektir. Günümüz şartlarındaki genel yargı, bireylerin kendi seçtikleri ve ilgi duydukları kişilerle evlenmelerinin daha uyumlu evlilikler oluşturacağı yönündedir (Kublay ve Oktan, 2015). Tanışıp evlenen bireylerin birbirlerinin kişilik özellikleri ve huylarına hâkim olması evlilik doyumunun düşmesinin en baştan önünü kesmiş olabilir.

\section{Evlililk Süiresi Değişkenine Göre Bulguların Tartışılması}

Anne babaların Ebeveyn Davranışları alt boyutları: Çocukla İlgilenme, Olumlu Ebeveynlik, Zayıf Ebeveyn Takibi, Tutarsız Disiplin ve Dayakla Cezalandırmaevliliksüresideğişkeninegöreanlamlıfarklılıkgöstermemektedir. Literatürde ebeveyn davranışlarının evlilik süresi değişkenine bağlı olarak değişip değişmediğini çalışan araştırmaya rastlanmamıştır. 
Anne babaların Evlilik Doyumu toplam puanı, Evlilik Uyumu ve Ebeveynlik Anlayışı alt boyutları evlilik süresi değişkenine göre anlamlı bir fark göstermemektedir. Literatürde bu bulguyu destekleyen çalı̧̧malar bulunmaktadır. Yanar Güngör (2019), Şentürk (2018), Berk (2009), Altun (2015), Çelik (2006), Çınar (2008), Çavuşoğlu (2011), Çağ (2011), Çağ ve Yıldırım (2013), Döner (2015), Gürsoy (2004), Kılıç (2017), Ovalı (2010) çalışmalarında evli bireylerin evli olma süresine göre evlilik doyumlarının anlamlı bir şekilde farklılaşmadığı görülmüştür.

Evlilik doyumu, ebeveynlik anlayışı ve evlilik uyumu alt boyutlarının, evlilik süresi değişkenine göre farklılaşmama sebebi, evli bireyler süreç içerisinde farklı rollere girmekte ve bunlara uyum sağlamaktadır. Evliliğin ilk yılları karı-koca olma durumuna alışmaya, eş olarak davranmaya uyum sağlamaya ve birbirlerinin özelliklerine adapte olmaya çalışarak geçmektedir. Sonrasında çocuğun varlığına uyum, çocuğun okul macerası, çocukların evden uzaklaşması gibi süreç içerisindeki birçok değişime adapte olmaya çalışan anne ve babanın evlilik yıllarına göre doyumun farklılaşmaması normal kabul edilebilir.

7.Ebeveyn Davranışları ile Evlililk Doyumu Arasındaki İliş̧kinin

\section{Tartışıllması}

Araştırma kapsamında yapılan korelasyon analizi sonucunda şu bulgular elde edilmiştir:

1- Evlilik Doyumu arttıkça Çocukla İlgilenme ve Olumlu Ebeveynlik davranışları artmaktadır. Evlilik Doyumu azaldıkça Zayıf Ebeveyn Takibi, Tutarsız Disiplin ve Dayakla Cezalandırma davranışları artmaktadır.

2- Evlilik Uyumu arttıkça Çocukla İlgilenme ve Olumlu Ebeveynlik davranışları artmaktadır. Evlilik Uyumu azaldıkça Zayıf Ebeveyn Takibi, Tutarsız Disiplin ve Dayakla Cezalandırma davranışları artmaktadır.

3- Ebeveynlik Anlayışı arttıkça Çocukla İlgilenme ve Olumlu Ebeveynlik davranışları artmaktadır. Ebeveynlik Anlayışı azaldıkça Zayıf Ebeveyn Takibi, Tutarsız Disiplin ve Dayakla Cezalandırma davranışları artmaktadır. 
Araştırma sonucu incelendiğinde ebeveyn davranışlarının olumlu 2 boyutu evlilik doyumunun artması ile artmaktadır. Ebeveyn davranışlarının olumsuz 3 boyutu da evlilik doyumunun azalmasıyla ilişkili çıkmıştır.

Anne babaların ebeveyn davranışları ile evlilik doyumu arasında anlamlı ilişki çıkmıştır. Bu sonuçlar beklenen ve istenilen yöndedir. Literatürde çocukların sosyal beceri gelişiminin, çocuk yetiştirme ortamından etkilendiğine dair çalışma (NICHD Early Child Care Research Network, 2002), çocukların sosyal uyumları ile anne babanın evlilik çatışmasının etkilerine dair çalışma (Güngören 2011), çocukluk ve ergenlik döneminde suçluluk davranış bozuklukları gibi davranışların ebeveyn davranışları ile ilişkili olduğu çalışma (Gross, Fleming, Mason ve Haggerty, 2015) madde kullanım bozukluğu olan ergenlerde anne babanın birlikteliğini düşük olduğuna ve ebeveynlerinin çift uyumunun düşük olduğu çalışma (Öngel Atar, Yalçın, Uygun, Çiftçi Demirci, Erdoğan, 2016) çocuk davranış bozuklukları ile evlilik doyumu arasında ilişki olduğuna dair çalışma (Jouriles, Bourg ve Farris,1991) bulunmaktadır. Bu çalışmalardan da anlaşılacağı üzere çocuk davranışları evlilik doyumundan ve ebeveyn davranışlarından etkilenmektedir.

\section{ÖNERILER}

$\mathrm{Bu}$ çalışma sonucunda araştırma sonuçlarından yola çıkılarak araştırmacılara aşağıdaki öneriler sunulabilir.

1. Bu araştırmanın Gaziantep-Şahinbey ilçelerine bağlı 7 farklı ilkokulda çocuğu olan 400 tane ebeveyne yapılmış olması, sonuçların genellenebilmesi açısından sınırlılık oluşturduğu için sonraki çalışmalarda daha genişörneklem grubuyla çalışılmasının daha faydalı olacağı düşünülmektedir.

2. Araştırma sonuçlarında ebeveyn davranışlarının olumsuz alt boyutlarıyla evlilik doyumunun negatif düzeyde ilişkili olduğu görülmüştür. Bireylerin evliliklerinden doyum sağlamaları ebeveyn davranışlarını etkilemektedir. Öncelikle anne babalara sağlıklı ebeveyn davranışlarına bilgilendirme yapılabilir. Ebeveyn davranışlarının çocuğun hayatın önemli bir rolünün olduğuna dair bilgilendirmeler yapılabilir. Ayrıca evlilik doyumunu artıracak grup çalışmaları, evliliğe dair eğitimler de düzenlenebilir. 
3. Araştırma sonunda babaların zayıf ebeveyn takibi davranışının yüksek olduğu sonucuna ulaşılmıştır. Babaları ebeveyn olma sürecine dâhil edecek çalışmalar yapılabilir.

4. Dayakla cezalandırma davranışı eğitim düzeyi arttıkça azalmaktadır. Bu sonuca göre eğitim düzeyi düşük anne babalara çocuk davranışları ve olumlu disiplin yöntemleri ile ilgili eğitim verilebilir.

5. Görücü usulü evlenen bireylerin zayıf ebeveyn takibi ve dayakla cezalandırma ebeveyn davranışları fazla çıkmıştır. Bu sonuca göre görücü usulü evlenen bireylere çocukların eğitimi ile ilgili daha fazla eğitim verilebilir.

6. Evlilik doyumu ve evlilik uyumu eğitim düzeyi arttıkça artmaktadır. Eğitim düzeyi düşük olan bireylere evlilik doyumunu artıracak çalışmalar yapilabilir. 


\section{KAYNAKÇA}

Aktürk, B. E. (2006). Marital Satisfaction in Turkish Remarried Families: Comparison Among Marital Status, Effect of Step children, and Contributing Factors. Yayımlanmamış Yüksek Lisans Tezi. Orta Doğu Teknik Üniversitesi Sosyal Bilimler Enstitüsü.

Altun, G. (2015). Evli Bireylerde Bağlanma Tarzları Ve Erken Dönem Uyumu Bozucu Şemaların Evlilik Doyumu İle İlişkisi. Yüksek Lisans Tezi. Üsküdar Üniversitesi Sosyal Bilimler Enstitüsü.

Anar B. (2011). Evli ve çalışan yetişkinlerin toplumsal cinsiyet rolleri ile evlilik doyumu ve iş doyumu ilişkisinin incelenmesi. Yüksek lisans tezi, Çukurova Üniversitesi.

Angusamy, A., Kuppusamy, J., Anantharaman, R. N., \& Syafiqah, S. A. (2017). Study on marital satisfaction among Malaysian women. International Journal for Studies on Children, Women, Elderlyand Disabled,1, 85-89.

Benedetto, L. ve Ingrassia, M. (2015). What connections between Marital conflict and Parenting Quality? Evidence from parent's gender in spillover effects. Mediterranean Journal of Clinical Psychology MJCP, 13(2) : DOI: 10.6092/2282-1619/2015.3.1066.

Berk, M. (2009). Evli öğretmenlerin yükleme tarzları ve evlilik doyum algılarının bazı demografik değişkenler açısından incelenmesi. Yüksek lisans tezi. Çukurova Üniversitesi Sosyal Bilimler Enstitüsü.

Bildirici, A. (2016). Evlilik süresinin, cinsel yaşama ve evlilik uyumuna etkisi ve sonuçların demografik özelliklere göre karşılaştırılması. Yüksek lisans tezi. Beykent Üniversitesi Sosyal Bilimler Enstitüsü.

Can, A. (2014). SPSS İle Bilimsel Araştırma Sürecinde Nicel Veri Analizi. 3. Baskı. Ankara: Pegem Akademi Yayıncılık.

Canel, A.N. (2007). Ailede Problem Çözme, Evlilik Doyumu Ve Örnek Bir Grup Çalışmasının Sinanması. Doktora Tezi. Marmara Üniversitesi Eğitim Bilimleri Enstitüsü.

Chandrakanth, J. (2015). Marital coping style among working and non-working women. International Jounal of Management and Social Science, 3(6), 57-64.

Çağ, P. (2011). Evli Bireylerde Eş Desteği Ve Evlilik Doyumu. Yüksek Lisans Tezi. Hacettepe Üniversitesi Sosyal Bilimler Enstitüsü.

Çağ, P. Ve Yıldırım, İ. (2013). Evlilik Doyumunu Yordayan İlişkisel Ve Kişisel Değişkenler. Türk Psikolojik Danışma Ve Rehberlik Dergisi, 4 (39), 13-23. 
Çakır, A. (2017). Anne Baba Tutumunun, Evlilikte Uyum Ve Sorun Çözme Becerisine Etkisinin İncelenmesi. Yüksek Lisans Tezi. Haliç Üniversitesi Sosyal Bilimler Enstitüsü.

Çekiç, A., Türk, F., Buğa, A., Hamamcı, Z. (2018). Alabama Ebeveyn Davranışları Ölçeği 'nin Türkçe 'ye Uyarlanması: Geçerlik Ve Güvenirlik Çalışması. Elektronik Sosyal Bilimler Dergisi, 17(66), 728-743.

Çelebi Öncü, E. Ve Ünlüer E. (2012). Parent s’ Attitude Towards Their Children Before and After Parental Education. Procedia - Social and Behavioral Sciences, 46, 5933 - 5936.

Çelik, M. (2006). Evlilik Doyum Ölçeği Geliştirme Çalışması. Doktora Tezi. Çukurova Üniversitesi Sosyal Bilimler Enstitüsü.

Çınar, L. (2008). Evlilik doyumu: Cinsiyet rolleri ve yardım arama tutumu. Yayımlanmamış yüksek lisans tezi. Gazi Üniversitesi Sosyal Bilimler Enstitüsü.

Çıtışlı Turgut, M. K. (2018). Evlilik Çatışması Ve Evlilik Doyumu Arasındaki İlişkide Affetmenin Aracı Rolü. Yüksek Lisans Tezi, Hasan Kalyoncu Üniversitesi Sosyal Bilimler Enstitüsü, Gaziantep.

Çiftçi, O. (1991). Çocuğun Sosyalleşmesinde Ailenin Rolü. Aile ve Toplum, 1(2).

Demiray, Ö. (2006). Evlilikte uyumun demografik özelliklere göre incelenmesi. Yüksek lisans tezi. Dicle Üniversitesi Sosyal Bilimler Enstitüsü.

Doğru, D. (2017). Üniversite Öğrencilerinde Algılanan Anne Baba Tutumlarının Eş Seçme Stratejileri Ve Evlilik Tutumu İle İlişkisi. Yüksek Lisans Tezi. İstanbul Gelişim Üniversitesi Sosyal Bilimler Enstitüsü.

Döner, A. Ç. (2015). Cinsel mitlerin, evlilik doyumu ve toplumsal cinsiyet rolleri arasındaki ilişkisinin incelenmesi. Yüksek lisans tezi. Üsküdar Üniversitesi Sosyal Bilimler Enstitüsü.

Elgar, F.J., Waschbusch, D.A., Dadds, M. R. ve Sigvaldason, N. (2007). Development and Validation of a Short Form of the Alabama Parenting Questionnaire. Journal of Child and Family Studies, 16, 243. https://doi.org/10.1007/s10826-006-9082-5.

Eminoğlu, B. (2007). Dört-Beş Yaş Çocuklarının Sosyal Davranışları İle Ebeveyn Davranışları Arasındaki İlişkinin İncelenmesi. Yüksek Lisans Tezi. Gazi Üniversitesi Eğitim Bilimleri Enstitüsü.

Erden, A. D. (2016). Kendini izleme tarzı, yakın ilişkilerde yaşanan kaygı ve algılanan eş davranışlarının evlilik doyumu üzerine etkisinin incelenmesi. Yüksek lisans tezi. Ege Üniversitesi Sosyal Bilimler Enstitüsü. 
Escribano, S.,Aniorte, J. Ve Orgilés, M. (2013). Factor structure and psychometric properties of the Spanish version of the Alabama Parenting Questionnaire (APQ) for children. Psicothema, 25(3), 324-329. Doi: 10.7334/psicothema2012.315.

Fine, M.A., Voydanoff, P. Ve Donnelly, B.V. (1994). Parental Perceptions of Child WellBeing: Relations to Family Structure, Parental Depression, and Marital Satisfaction. Journal Of Applied Developmental Psychology, 15, 165-186.

Fishman, E.A. \& Meyers, S.A. (2000). Marıtal Satısfactıon And Chıld Adjustment: Direct And Mediated Pathways. Contemporary Family Therapy, 22,437. https://doi. org/10.1023/A:1007848901640.

Frick, P. J. (1991). The Alabama parenting questionnaire. Unpublished rating scale, University of Alabama.

Garip, E.S. (2010). 5-6 Yaş Döneminde, Okul Öncesi Eğitim Kurumuna Devam Eden Çocuğu Olan Eşlerin Çocuk Yetiştirme Stilleri İle Evlilik Uyumları Arasındaki İlişkinin İncelenmesi. Yüksek Lisans Tezi. Marmara Üniversitesi Eğitim Bilimleri Enstitüsü.

Glenn, N. D. (1991). The recent trend in marital success in the United States. Journal of Marriage and the Family, 261-270.

Goldberg, W.A. (1990). Marital Quality, Parental Personality, and Spousal Agreement About Perceptions and Expectations for Children. Merrill-Palmer Quarterly, 36(4), 531-556.

Greef, A.P. (2000). Characteristics of families that function well. Journal of family Issues, 21(8), 948-962.

Gross, T.J., Fleming, C.B., Mason, W.A. ve Haggerty, K.P. (2015). Alabama Parenting Questionnaire-9: Longitudinal Measurement Invariance Across Parents and Youth During the Transition to High School. Sage Journals, 1-14. DOI: 10.1177/1073191115620839.

Guerro, L.K. ve Eloy, S.V. (1992). Relational Satisfaction and Jealousy Across Marital Types. Communication Reports, 5(1), 23-31. DOI: 10.1080/08934219209367540.

Günayer Şenel, H. (2017). Eş Seçim Kararı. H. Yavuzer, (Ed.), Evlilik Okulu içinde (ss.6191).

Güren, A.S. (2017). Evli Ve Çocuk Sahibi Çiftlerin Evlilik Uyumu, Evlilik Çatışması, Yakın İlişki Düzeyi Ve Yalnızlık Düzeylerinin Çocuk Yetiştirme Tutumları İle İlişkisi. Yüksek Lisans Tezi. İstanbul Ticaret Üniversitesi Sosyal Bilimler Enstitüsü. 
Gürsoy, Ç. (2004). Kaygı ve demografik değişkenlerin evlilik uyumu ile ilişkisi. Yüksek lisans tezi. Mersin Üniversitesi Sosyal Bilimler Enstitüsü.

Güven, N. (2005). İlişkilerle İlgili Bilişsel Çarpıtmalar Ve Evlilikte Problem Çözme Becerilerinin Evlilik Doyumu İle İlişkisi. Yüksek Lisans Tezi. Ankara Üniversitesi Eğitim Bilimleri Enstitüsü.

Hamurcu, G. (2018). Paternal Bağlanma İle Evlilik Doyumu Arasındaki İlişkinin İncelenmesi. Yüksek Lisans Tezi. Beykent Üniversitesi Sosyal Bilimler Enstitüsü.

Howes, P.,\& Markman, H. (1989). Marital Quality and Child Functioning: A Longitudinal Investigation. Child Development, 60(5), 1044-1051. doi:10.2307/1130778.

İșmen Gazioğlu, E. (2017). Aile Yaşam Döngüsü. H. Yavuzer, (Ed.), Evlilik Okulu içinde (ss.22-47).

Jouriles, E. N., Bourg, W.J, \& Farris, A.M., (1991). Marital adjustment and child conduct problems: a comparison of the correlation accross subsampies. Journal of Consulting and Clinical Pychology, 59(2), 354 - 357.

Karasan, S. (2015). Bireylerin Ebeveynlerinin Göstermiş Oldukları Ebeveyn Tutumları İle Sahip Oldukları Düşünme Stilleri Arasındaki İlişki. Yüksek Lisans Tezi. Haliç Üniversitesi Sosyal Bilimler Enstitüsü.

Kaya, İ. (2003). Evlilik Uyumu ile Çocuklardaki Davranış Problemleri Arasındaki İlişkide Çocuk Yetiştirme Tutumlarının Rolü. Yüksek Lisans Tezi, İstanbul Üniversitesi Sosyal Bilimler Enstitüsü.

Kaya, S. (2005). Ergenlikte Kendine Güven ve Aile İle İlişkilendirilmesi. Yüksek Lisans Tezi. Selçuk Üniversitesi Sosyal Bilimler Enstitüsü.

Mazefsky, C.A. \& Farrell, A.D. (2005). The Role of Witnessing Violence, Peer Provocation, Family Support, and Parenting Practices in the Aggressive Behavior of Rural Adolescents. Journal of Child and Family Studies, 14(1), 71-85. https://doi. org/10.1007/s10826-005-1115-y.

NICHD Early Child Care Research Network (2002). Early child care and children's development prior to school entry: results from the NICHD study of early child care. American Educational Research Journal, 39(1), 33-164. DOI: 10.3102/00028312039001133. 
ÇALIŞMALARI DERGISI $\mid$ YIL: 21 SAYI: 51 MART - HAZIRAN 2021

Ovalı, H. (2010). Farklı Coğrafi Bölgelerde Yaşayan Bireylerin Evlilik Çatışmalarının Çeşitli Demografik Özelliklere Göre Karşılaştırılması. Yüksek Lisans Tezi. Gazi Üniversitesi Eğitim Bilimleri Enstitüsü.

Öngel Atar, A., Yalçın, Ö., Uygun, E., Çiftçi Demirci, A., Erdoğan, A. (2016). Madde Kullanım Bozukluğu Olan Ergenlerde Aile İşlevlerinin, Çift Uyumunun ve Anne Baba Tutumunun Değerlendirilmesi. Arch Neuropsychiatr, 53, 38-44.

Özabac1, N., Körük, S. Ve Kara A. (2019). A Metaphoric Examination of the Meaning of Marriage. Çukurova Üniversitesi Eğitim Fakültesi Dergisi, 48(1), 693-736.

Özaydınlık, Ş. (2014). Evli çiftlerin evlilik uyumu ile kişilik özellikleri ve romantik ilişkilerindeki sosyal ilginin incelenmesi. Yüksek lisans tezi. Marmara Üniversitesi Eğitim Bilimleri Enstitüsü.

Öztahtacı, D. (2017).Evli Kadınlarda Evlilik Doyumu, Yetişkin Bağlanma Stilleri Ve Depresyon Düzeyinin İlişkisinin İncelenmesi. Yüksek Lisans Tezi. Hasan Kalyoncu Üniversitesi Sosyal Bilimler Enstitüsü.

Özer, E. (2016). Evlilik Doyumu ve Çift İlişkisi. Akademisyen Kitapevi: Ankara

Robert, C. J. (2009). Parenting Practices and Child Behavior in Mexico: A Validation Study of the Alabama Parenting Questionnaire. The Faculty Of The Graduate School Of The University Of Minnesota.

Sarı, T. (2012). Evli Bireylerin Ebeveyn Algıları, Otomatik Düşünceleri Ve Bağlanma Stillerinin Evlilik Doyumu İle İlişkisi. Yüksek Lisans Tezi. Haliç Üniversitesi Sosyal Bilimler Enstitüsü.

Sebre, S. B., Jusiene, R., Dapkevice, E., Skreitule-Pikse, I., \& Bieliauskaite, R. (2014). Parenting dimensions in relation to pre-schoolers' behaviour problems in Latvia and Lithuania. International Journal of Behavioral Development, 39(5), 458-466. https:// doi.org/10.1177/0165025414548774.

Sevinç, M., Garip, E.S. (2010). A study of parents' child raising styles and marital harmony. Procedia-Social and Behavioral Sciences, 2; 1648-1653.

Servera1, M., Esposito, A., Garcia, G.B., Giudice, E.D. (2015). Factor Analysis of the Italian Version of the Alabama Parenting Questionnaire in a Community Sample. Journal of Child and Family Studies, 25, 1208-1217. DOI 10.1007/s10826-015-0291-7. 
Shelton, K. K., Frick, P. J., ve Wootton, J. (1996). Assessment of parenting practices in families of elementary school-age children. Journal of Clinical Child Psychology, 25, 317-329. doi:10.1207/s15374424jccp2503_8.

Soylu, Y ve Kabasakal, Z. (2016). Evli Kadınların Yaşam Doyumunun Evlilik Doyumu Ve Çalışma Durumu İle İlişkilerinin İncelenmesi. Journal of Research in EducationandTeaching, 5(4), 215-221.

Şentürk, E. (2018). Evlilikte Özyetkinlik, Ebeveyn Öz yetkinliği, Bilişsel Duygu Düzenleme Ve Evlilik Doyumu Arasındaki İlişki. Yüksek Lisans Tezi. İstanbul Üniversitesi Cerrahpaşa Lisansüstü Eğitim Enstitüsü.

Taşköprü, M. (2013).Evlilik Doyumu İle Problem Çözme Becerileri, Stresle Başa Çıkma Ve Evlilik Süresi Arasındaki İlişkinin İncelenmesi. Yüksek Lisans Tezi. İstanbul Bilim Üniversitesi Sosyal Bilimler Enstitüsü.

Tezer, E. (1994). Evlilik ve İş Doyumu İlişkisi: İkili Çatışmalar ve Bazı Demografik Değişkenlerin Rolü. Psikolojik Danışma ve Rehberlik Dergisi, 2(1), 1-12.

Tezer, E. (1996). Evlilik İlişkisinden Sağlanan Doyum: Evlilik Yaşamı Ölçeği. Psikolojik Danışma ve Rehberlik Dergisi, 2(7), 1-7.

Tozan, S. (2019). Çocukluk Çağı Travmalarının Evlilik Uyumu Ve Evlilik Doyumuna Etkisi. Yüksek Lisans Tezi. Üsküdar Üniversitesi Sosyal Bilimler Enstitüsü.

Turanlı, P. (2010). Orta Yetişkinlikte Evlilik Uyumu ile Benlik Saygısı ve Bağlanma Stilleri Arasındaki İlişkinin Saptanması. Yüksek Lisans Tezi. Maltepe Üniversitesi Sosyal Bilimler Enstitüsü.

Twenge, J.M., Campbell, W.K., Foster, C.A. (2003). Parenthood and marital satisfaction: a meta-analytic review. Journal of Marriage and Family, 65, 574-583.

Uçak, J. (2018). Çalışan Ve Çalışmayan Kadınlarda İletişim Becerilerinin Evlilik Doyumuna Etkisi. Yüksek Lisans Tezi. Üsküdar Üniversitesi Sosyal Bilimler Enstitüsü.

Uçar, E. (2018). Psikolojik İyi Oluş Yordayıcısı Olarak Dindarlık, Evlilik Doyumu Ve Problem Çözme. Yüksek Lisans Tezi. İstanbul Ticaret Üniversitesi Sosyal Bilimler Enstitüsü.

Vazquez, A.L, Domenech Rodríguez, M.L., Amador Buenabad, N.G., Bustos Gamiño, M.N., Lourdes Gutierrez López, M., Villatoro Velázquez, J.A. (2019). The influence of perceived parenting on substance initiation among Mexican children. DOI: https://doi.org/10.1016/j.addbeh.2019.05.026. 
Yalçın, F. ve Türnüklü, A. (2011). Algılanan ana-baba davranışları ile çocuk yetiştirme tutumları arasındaki İlişki. E-Journal of New World Sciences Academy, 6(1): 717-735.

Yanar Güngör, Z. (2019). Evli Bireylerde Yaşam Doyumunun Yordayıcısı Olarak Evlilik Doyumu Ve Bağlanma Boyutları. Yüksek Lisans Tezi. Çukurova Üniversitesi Sosyal Bilimler Enstitüsü.

Yıldırım, Ş. (2017). Görücü Usulü Evlenen Ve Flört Ederek Evlenen Çiftlerin Duygusal Farkındalık Ve Duyguları Iffade Etme Düzeylerinin Evlilik Doyumuna Etkisi. Yüksek Lisans Tezi. Beykent Üniversitesi Sosyal Bilimler Enstitüsü.

Yıldız, A. (2013). Anne Baba tutumları ile evlilik doyumu arasındaki ilişkinin incelenmesi. Yüksek Lisans Tezi. Fatih Üniversitesi Sosyal Bilimleri Enstitüsü.

Yıldız, Ö. Z. (2018). Evlilik Doyumunun Öncülleri Ve Sonuçları: Depresyon, Kaygı, Erken Dönem Uyumsuz Şemalar. Yüksek Lisans Tezi. Işık Üniversitesi Sosyal Bilimler Enstitüsü.

Yilmaz, M. (2015). Evli Bireylerin Bağlanma Stillerinin, Bireylerin Umutsuzluk Düzeyi Ve Evlilik Uyumu Üzerindeki Etkisi. Yüksek Lisans Tezi. Işık Üniversitesi Sosyal Bilimler Enstitüsü.

Yücel, Y. (2013). Ortaokul Öğrencilerinin Algıladıkları Anne-Baba Tutumlarının, Benlik Saygısı Ve Öğrenilmiş Çaresizlik İle İlişkisi. Yüksek Lisans Tezi. Arel Üniversitesi Sosyal Bilimler Enstitüsü.

Yüksel, Ö. Ve Dağ, İ. (2015). Kadınlarda Evlilik Uyumu ve Psikolojik Belirtiler Arasındaki İlişki: Stresle Baş Etme Biçimleri ve Toplumsal Cinsiyet Rolü Tutumlarının Aracı Rolleri. Türk Psikiyatri Dergisi, 26(3):181-188. 